\title{
Institutional Factors Influencing the Size and Structure of Tourism: Comparing Dalarna (Sweden) and Maine (USA)*
}

\author{
David Vail \\ Bowdoin College, Brunswick, Maine, USA
}

\section{Tobias Heldt}

Center for Transportation Economics, Dalarna University, Borlänge, Sweden

This paper explains why neither Maine, USA's comparatively laissez faire economic and land use institutions, nor Dalarna, Sweden's more heavily regulated economy, seems well designed to make tourism a powerful economic development engine. The paper focuses on three clusters of institutions that have a major influence on tourism's scale, economic structure, and long-term sustainability. Labour laws and labour market institutions are important determinants of tourism employment, job quality, product mix, production methods, and regional competitiveness. Land ownership and property rights influence both the incentives facing landowners, tourists, and tourism businesses and stresses on ecosystem carrying capacity. Commodity taxes affect the absolute and relative prices of various tourist services and, via feedback effects on demand, influence tourism's aggregate scale, activity mix and transportation/location patterns. The paper employs institutional contrasts between Dalarna and Maine to frame hypotheses that will guide a larger comparative study of sustainable tourism in forest regions. Perhaps most controversially, we hypothesise that Sweden's venerable right of common access (allemansrätten), as currently implemented, impedes sustainable tourism development. An appendix sketches the current state of tourism in the two regions.

\section{Purpose and Method}

This paper is the starting point for a study of strategies for economically sustainable nature tourism in forest regions. It focuses on three clusters of institutions that have a major influence on tourism's scale, economic structure, and long-term sustainability in Dalarna County, Sweden, and the US state of Maine. Tourism scale refers to magnitudes such as annual visitor numbers, guest nights at commercial establishments, total tourist spending, economic multiplier effects, and employment levels. ${ }^{1}$ Tourism's core structural characteristics are the mix of commercial and non-commercial recreation, seasonal distribution of visits, land ownership and business organisation patterns, and methods of producing tourist services. Sustainability, as used here, refers to tourist activities that meet two conditions: they function within ecological carrying capacity limits and they contribute to durable economic prosperity and social vitality in host regions.

The three key institutional clusters are described, compared, and contrasted:

... Labour laws and labour market institutions, which are important determinants of tourism employment, job quality, ${ }^{2}$ product mix, production methods, and regional competitiveness. 
... Land ownership and property rights, which affect tourism's economic potential by influencing the incentives facing landowners, tourists and tourist businesses, as well as the level of stress on ecosystem carrying capacity.

... Commodity taxes influence the absolute and relative prices of various tourist services and, through feedback effects on demand, affect tourism's aggregate scale, activity mix, and transportation/location patterns.

This paper uses institutional contrasts between Dalarna and Maine to frame the hypotheses that will guide our future investigations. Later sections present several such hypotheses and corollaries and flesh out the assertion that most Maine institutions lie near the laissez faire end of the political-economic spectrum, while Swedish tourism reflects more extensive state intervention in the economy and property rights. Labour, land, and tax institutions are by no means the only ones shaping tourism, but they are particularly important. Future research will include comparative investigation of additional public institutions, such as transportation networks, education and training, and tourism research.

\section{A co-evolutionary institutional perspective}

We employ a very basic notion of institutions, derived from the work of economist Douglas North and summarised by Folke et al.:

By institutions we mean the humanly devised constraints that shape human interaction and the way societies evolve through time. Institutions are made up of formal constraints (rules, laws, constitutions), informal constraints (norms of behavior, conventions and self-imposed codes of conduct), and their enforcement characteristics. (Folke et al., 1997: 3)

Starting from this broad understanding of institutions, it should be clear that tourism in industrial societies is enmeshed in a web of institutions, with strands running from markets to property rights and from environmental ethics to public policies. This is the matrix within which tourism's key players - tourism service producers, trade associations, land owners, travel agents, seasonal employees, labour unions, local officials, national governments and, of course, leisure travellers themselves - make decisions and take action. Our premise is that, if we hope to explain the behaviour of individuals and organised interests and identify their cumulative effects, we must first understand the institutional rules and norms that shape behaviour. This essay attempts to unravel webs made up of both deliberately designed and informally evolved institutions and to show the major impact they have had on the scale and structure of tourism in two places, Maine (USA) and Dalarna (Sweden). It demonstrates how particular institutional differences operating within broadly similar societies can lead to quite different economic, equity and environmental outcomes.

The emphasis on institutionalised relationships and behaviour also reflects an interpretation of institutions as an important part of every society's accumulated 'capital'. Institutional assets, such as shared values, knowledge and ethical standards can contribute to or detract from a collective purpose, in this case sustainable tourism development. Institutional capital can be accumulated through deliberate investments (e.g. in legislation, education, formation of private organisations) or it can depreciate through neglect. From an evolutionary 
perspective, a lack of institutional resilience in the face of changing conditions and collective purposes can render ineffective or even counterproductive institutions that were once highly effective. For example, several features of both Swedish and American labour market policy have proven to be maladapted to the policy objective of expanding the number of high quality tourism jobs in distressed rural regions.

In contrast, institutions may adapt and prove resilient in changing circumstances. For example, private landowner associations have been created in both Maine and Dalarna to reduce transaction costs and capture infrastructure economies of scale in back country recreation. Government measures to promote such private institutional innovations are particularly intriguing (Becker \& Ostrom, 1995; Folke et al., 1997).

\section{Dalarna and Maine: A 'quasi-experiment'}

A few words are in order about why Dalarna County and interior Maine were chosen as a basis for assessing the potential for sustainable tourism development. Well before tourism became a mass phenomenon toward the end of the last century, Dalecarlia's visitors, including story-teller H. C. Andersen and heritage park builder Arthur Hazelius, and travellers in Maine's vast northern wilderness, such as naturalist Henry David Thoreau and novelist Nathaniel Hawthorne, were shaping a cultural mystique that still surrounds these places. The mystique was reinforced in the popular imagination by turn-of-the-century artists such as Carl Larsson, Anders Zorn and Winslow Homer. A century later, Dalarna and Maine still retain the special allure of places that are accessible and yet 'off the beaten path', with distinctive folkways and stunning lake and mountain scenery. ${ }^{3}$

Dalarna and Maine are both predominantly rural, with extensive mountain ranges and thousands of lakes and ponds. With the return of marginal farmland to forest, over $90 \%$ of the land area is forested. Three-fourths of Dalarna's land area is privately owned, while the Maine figure is close to $95 \%$. The southern parts of both regions are within an easy day's drive for prospective visitors from major metropolitan centres: Stockholm, Göteborg, and Oslo; Boston, New York, and Montreal. Economic conditions in both places historically rose and fell with the fortunes of natural resource-based industries, which, for complex reasons, are now mature or declining.

Policy makers seeking new rural development opportunities have identified tourism as a clean, green, and labour intensive way to grow: exploiting underutilised natural and human capital, diversifying the economic base, creating jobs, and revitalising rural communities. This ambition is reflected in Maine's 1995 tourism Marketing and Development Strategy: 'Within the context of an emerging global economy, the grow th of the tourism industry ... brings jobs and stability to the state' (MOT, 1995: 2). The strategy sets a tourism growth target of $3 \%$ per year, compared to $2+\%$ for the overall economy. Dalarna's County Board echoes that, 'There are big hopes in the county for an increase in tourism and employment within tourism. These hopes take as their starting point that Dalarna is [already] a major tourist county and that tourism internationally is one of the fastest growing industries'(LD, 1998: 3). Beyond its contributions to income, employment and tax revenues, Dalarna tourism is expected to help 
maintain quality of life in host communities via better physical facilities, social services and cultural activities.

There is, in particular, a widespread conviction that 'Nature' has a unique and increasingly important place in the leisure life of very large nearby populations. Maine tourism promotions make much of the fact that the state has the largest contiguous forest 'wildland' east of the Mississippi River, including the only designated wilderness waterway, the northern terminus of the $3000 \mathrm{~km}$ Appalachian Trail, and 40,000 moose to shoot with camera or rifle. Sahlberg paints a similar picture of interior Sweden:

The environment in its entirety with clean air and clean waters, the lack of noise and crowding has got qualities that seldom are found at other places in Europe... These conditions together with the Swedish right of common access make these areas unique in Europe. (Sahlberg, 1998: 229)

In sum, Dalarna and Maine offer a fruitful basis for comparative study of tourism development for two reasons. First, there are important historic, geographic and economic parallels. Second, policy makers are convinced their jurisdictions are uniquely situated to make tourism a major engine of economic growth. This paper explains why, in fact, neither Maine's comparatively laissez faire institutions nor Dalarna's more heavily regulated tourism seems well designed for that purpose. Although Dalarna and Maine do not offer a controlled laboratory to investigate institutional variations, the overlay of specific differences on basic institutional similarities gives us a promising 'quasi-experiment' for generating and testing hypotheses.

\section{Labour Market Institutions: Costs, Rigidities and Incentives}

\section{Dalarna's high cost tourism labour}

There are no regional or sectoral differences in Sweden's labour laws and institutions; thus what goes for Sweden also goes for Dalarna. Historically, Swedish wage formation and the regulations governing many labour market institutions were based largely on conditions in manufacturing industries, where full-time, career-long jobs were the norm. Today service sectors employ most workers, and part-time and limited-term employment have become much more common. Public policies and collective bargaining arrangements designed for other sectors and earlier times have a major impact upon the rural tourism labour market.

\section{Unionisation, collective agreements and average tourism wages}

Sweden has no statutory minimum wage. Instead, collective agreements between employee organisations and employer organisations or individual employers regulate pay arrangements within each line of business. For tourism industry employees, the 1997 starting hourly wage for adult workers was SEK 65 $(\$ 8.70)$, but the average gross wage reported by the Hotel and Restaurant union, which organises most tourist industry employees, was SEK 96/hour (\$12.80). Gross wages include vacation pay and supplements for night and weekend work $^{4}$ (HoR, 1998). Table 1 shows the wide range of annual earnings in various tourism-related sub-sectors. (The 'All Tourism' figure is a weighted average 
Table 1 Average annual gross earnings in tourism sub-sectors (1994) ${ }^{\mathrm{a}}$

\begin{tabular}{||l|r|c||}
\hline Sector & Average Earnings & \% of service sector average \\
\hline All Services & SEK169,100 $(\$ 22,500)$ & 100 \\
\hline All Tourism & $158,500(\$ 21,100)$ & 94 \\
\hline Hotel and restaurant & $114,300(\$ 13,300)$ & 68 \\
\hline Ground transport & $166,400(\$ 22,200)$ & 98 \\
\hline Air transport & $281,000(\$ 37,500)$ & 167 \\
\hline Travel bureau & $192,600(\$ 25,700)$ & 114 \\
\hline Recreation, culture, sport & $159,400(\$ 21,300)$ & 94 \\
\hline
\end{tabular}

a Excludes mandatory employer-financed benefits

Source: TD, $1998 \mathrm{a}$

across occupational groups, e.g. hotel managers and chambermaids; airline pilots and ground crews.) Average earnings in tourism are held down by the preponderance of relatively poorly educated, low paid, and frequently seasonal hotel and restaurant workers. As a group, tourism employees have significantly less education than all service sector employees: $31 \%$ have just a nine year elementary school education, compared to $19 \%$ of all service employees; only $16 \%$ have post-secondary education, versus $32 \%$ of all service employees (TD, 1998a).

Roughly 70\% of employees in tourism's various sub-sectors are trade union members, which is about average for Sweden's private services. Union membership varies within tourism, with high-skill, year-round workers such as cooks and buffet managers $90 \%$ unionised, and less skilled and more seasonal groups, like chambermaids, at about 50\% (HoR, 1998). Unionisation raises wages above the competitive market level, and the much higher rate of union membership in Dalarna compared to Maine probably explains part of the big wage differences revealed in the sub-section on Maine, below. Unions also work to secure better non-wage conditions for their members.

\section{Swedish labour law and the collective agreement}

The generic term for statutes governing work conditions, workers' rights and collective bargaining is labour law. Labour legislation has given workers several rights, including the right to participation in workplace decision-making, paid vacations, limited working hours, improved working environment, and increased employment security. An employee's most important protection is The collective agreement, a written, signed contract between the labour organisation and employer organisation or individual employer which specifies obligations for both parties. It functions for the employee in the same way as legislation, such as the Working Hours Act or the Annual Leave Act. Apart from provisions concerning pay and work conditions, the collective agreement gives employees supplementary insurance protection and pension contributions, beyond the mandatory employer contributions discussed below. In the USA and several other countries minimum wage laws provide one protection that the collective agreement gives in Sweden, where as mentioned, there is no such legislation. The collective agreement is widely viewed as giving workers more effective protection in Sweden than in most other countries (LO, 1999). 
Table 2 Mandatory employer contributions (\% of gross wage)

\begin{tabular}{||l|c||}
\hline Old age pension & 6.40 \\
\hline Survivors' pension & 1.70 \\
\hline Sickness insurance & 7.50 \\
\hline Parental leave insurance & 2.20 \\
\hline Occupational injury insurance & 1.38 \\
\hline Labour market contribution & 5.84 \\
\hline General payroll & 8.04 \\
\hline Total & 33.06 \\
\hline
\end{tabular}

Source: LO, 1999

\section{Mandatory employer contributions and total labour costs}

Tourist sector employers make mandatory contributions, currently $33.06 \%$ of the gross wage (see Table 2).

These benefits extend to tourism's part-time and seasonal employees. In addition, full-time employees receive 25 days of annual paid vacation, while seasonal workers receive a $13 \%$ hourly wage supplement in lieu of vacation. Self-employed tourist entrepreneurs must pay fees similar to mandatory employer contributions (at $31.05 \%$ of salary), as well as income tax. Combining mandatory employer contributions with gross wages, the average labour cost for hourly tourism workers is approximately SEK 128/hour (\$17.07), or about twice the Maine figure reported below. In addition to the mandatory contributions, most employers make supplementary insurance and pension contributions, currently $5.15 \%$ of the gross wage.

\section{Unemployment insurance, layoff legislation and seasonal employment patterns}

Another institution affecting tourism's labour costs, incentives, and labour market flexibility is the unemployment insurance system. To be eligible for unemployment benefits, a person must have worked at least six months in the past year; the majority of seasonal tourism employees receive benefits during the 'off season'. Eligible workers receive up to $80 \%$ of their immediate past monthly wage, to a maximum of SEK 580 (\$77) per day (Eriksson, 1999; HoA, 1998).

This generous eligibility rule acts like a subsidy to seasonally dependent industries like tourism and their part-year employees. The artificial increase in year-round compensation probably inflates tourism's labour supply and reduces wages, since employees know they will be compensated when laid off. Employers can more readily vary labour input and production costs in response to seasonal demand fluctuations. Research confirms that Sweden's comparatively generous unemployment compensation increases labour market flexibility and reinforces underlying seasonal employment fluctuations (Hultkrantz et al., 1987). Employment security legislation, known as LAS, governs layoffs, prior notification, etc. In general, LAS works against seasonal and temporary employment, but in the tourist industry specifically, seasonal layoffs are allowed. To benefit from LAS protections, a worker must have had at least six months of employment within the last two years. 
Regulations regarding normal work hours and layoffs also affect labour market flexibility. Since tourist demand fluctuates widely by season, many employers have an interest in extending work hours at peak seasons and cutting them in slack periods. By keeping more permanent, year-round employees, they can reduce recruitment, training and management costs. The 1982 Working Hours Act (SFS, 1982: 673) set the normal work week at 40 hours, averaged over a four week period. However, a 1995 law allows averaging of hours over a full year with the agreement of the collective bargaining agents (HoR, 1998). This mechanism is increasingly used by the larger tourism employers, which number 20 to 30 in Dalarna (Persson, 1999). Such flexibility reduces seasonal employment fluctuations and further expansion of work-time averaging might also reduce financial pressure on the unemployment compensation system.

\section{Maine's 'cheap labour' tourism}

Maine tourism operates in a quasi-free market environment, encouraging employers to adopt a 'cheap labour' strategy by hiring relatively unskilled workers and producing services with labour-intensive methods. The key public institutions, elaborated below, are a low statutory minimum wage, low payroll taxes, limited employer-financed benefits, and minimal restrictions on layoffs. Two key features of the private institutional environment are free market ideology and negligible unionisation of tourism workers. We will refer below to the notion of a 'livable wage'. This concept has been defined by a prestigious public-private body, the Maine Economic Growth Council, as the minimum full-time earnings required to pay for a two-person household's basic necessities. Operationally, the livable wage is set at $185 \%$ of the official poverty threshold. In 1998, the last year for which comprehensive occupational wage data are available, the livable wage threshold was $\$ 9.46 /$ hour. In 1968, 68\% of Maine workers received a livable wage. As a point of reference, the Economic Growth Council set a goal of $85 \%$ livable wage jobs by the year 2005 .

\section{The minimum wage and tourism wage formation}

Since late 1997, the US minimum wage has been $\$ 5.15 /$ hour (SEK 38.6), or 64\% of the Swedish level. ${ }^{5}$ Several states, including four of Maine's five New England neighbors but not Maine itself, have enacted higher minimum wages. The US Congress adjusts the legal minimum upward periodically, but its long-term purchasing power has declined. In fact, 'hospitality industry' lobbying has been a major force against higher federal and Maine minimum wages. ${ }^{6}$ An individual with no dependants would have to be employed full time at $\$ 5.25 /$ hour just to reach the official US 'poverty line'. As noted above, Maine's livable wage threshold was \$9.46 in 1998. The state's average wage was \$12.07 in that year (MDOL, 2000).

Wage formation in Maine's tourist services is not significantly distorted by market power on either side of the labour market. At least three-fourths of tourism employment is in three sub-sectors, eating places, lodging establishments and retail outlets. On the supply side, almost no workers in these sub-sectors belong to labour unions or are covered by collective bargaining agreements. ${ }^{7}$ On the demand side, most businesses serving tourists are very small relative to their local labour markets. (There are exceptions, such as ski resorts in sparsely populated rural areas.) There is no complete or unbiased survey of tourism wages and 
Table 3 Average hourly wages in Maine's key tourism sub-sectors

\begin{tabular}{||l|c|c|c|c|c||}
\hline \multirow{2}{*}{ Sector } & \multirow{2}{*}{$\begin{array}{c}\text { \% of total tourist } \\
\text { spending }\end{array}$} & \multicolumn{2}{|c|}{ Average hourly wage } & & \\
\cline { 1 - 5 } & 44 & 1994 & 1998 & & \\
\hline Retail sales & $\$ 4.59$ & $\$ 8.35$ & SEK & 62.6 \\
\hline Food \& alcohol & 24 & 6.46 & 7.10 & & 53.3 \\
\hline Lodging & 17 & 6.76 & 7.44 & & 55.8 \\
\hline Recreation & 10 & 7.08 & 7.79 & & 58.4 \\
\hline Total & 95 & 1998 weighted average & $\$ 7.42$ & SEK & 55.2 \\
\hline
\end{tabular}

Sources: MDOL, 2000; MEGC, 1998: 5; Vail et al., 1998: 43

salaries, but based on survey data from lodgings and restaurants plus state wage statistics for key tourism services, we are confident Table 3 presents accurate orders of magnitude for the majority of tourism's hourly employees.

Normative evaluation of these low wages is complicated by the fact that many workers take tourism jobs by choice, seeking seasonal or part-time work to complement activities such as education, domestic work, farming and forestry. It is nonetheless pertinent that the median wage for motel room maids, retail sales clerks, and non-tipped food sector employees is barely above the official poverty threshold for an individual. In 1998 only about one-fourth of hourly paid tourism workers received the $\$ 9.46$ wage needed to meet a small family's basic needs budget (Vail \& Kavanaugh, 2000: Appendix 1). Prominent Maine policy makers urge an increase in tourism promotion, arguing that it will create jobs; but such a strategy is questionable when most tourism jobs pay so poorly. Policy makers seem also not to grasp that a cheap labour strategy in effect subsidises tourists and owners of labour-intensive tourist businesses. The cheap labour strategy also has hidden social and fiscal costs, including higher state and local taxes to finance health and welfare benefits for the working poor and the near-poor (BLE, 1991).

Of course thousands of self-employed and wage earning tourism workers earn much more than the average hourly wage. Even among the hourly workers the wage distribution is skewed, with the median $15-20 \%$ below the average in restaurants and lodgings (MDOL, 1997: 153). In the special conditions of southern and coastal Maine, where tight labour markets have pushed summer unemployment rates down to 1.7-2.5\% since 1997, even low-skill, entry-level workers receive wages approaching the averages in Table 3 . The average salaries of managerial employees in lodgings and restaurants (c. $20 \%$ of employees) are equivalent to hourly wages of $\$ 9.31$ (SEK 69.8), and \$9.51 (SEK 71.3), respectively, and operators of expensive southern Maine restaurants report that their tipped waiters earn more than $\$ 15$ (SEK 113)/ hour in the peak season. At the 'top of the heap' are several thousand business owners, craftspeople, entertainers, sporting guides and other highly skilled tourism service providers. By our estimate, $38 \%$ of all people engaged in tourism occupations earned a livable wage in 1998, dramatically below the $68 \%$ figure for the entire Maine workforce (Vail et al., 1998: 42; Vail \& Kavanaugh, 2000: Appendix 1).

Mandatory and voluntary employer contributions and total labour costs

All employers contribute to the federal Social Security (SS) and state Unemployment Insurance (UI) funds and make Workers' Compensation (WC) 
Table 4 Cost of mandatory employer contributions

\begin{tabular}{|l|c|c|c|c||}
\hline & \% of payroll & \multicolumn{3}{|c||}{ Average hourly cost $t^{a}$} \\
\hline Social Security & 6.25 & $\$ 0.46$ & SEK & 3.45 \\
\hline Unemployment Insurance & $3.2^{\mathrm{b}}$ & 0.24 & & 1.80 \\
\hline Workers' Compensation & $2.5^{\mathrm{c}}$ & 0.19 & & 1.43 \\
\hline Total & 11.95 & $\$ 0.89$ & SEK & 6.68 \\
\hline \hline
\end{tabular}

a Based on an average tourism wage of $\$ 7.42$ in 1998.

${ }^{\mathrm{b}}$ Currently, small employers pay $2.8 \%$ on the first $\$ 7000$ of an employee's wages plus a $0.4 \%$ surcharge to maintain the UI system's solvency.

${ }^{\mathrm{c}}$ Estimated average for all tourism employment.

Sources: Kimball, 1999; Murphy, 1999

insurance payments to cover job-related accidents, injury and illness. WC insurance premiums vary according to sectors' past health and safety records. In three low risk, low stress activities that contribute much tourism employment - hotels, restaurants and retail clothing stores - WC as a share of payroll costs is $2.7 \%, 2.2 \%$ and $1.3 \%$ respectively. Riskier and more stressful tourism activities, such as amusement parks (3.7\%) and alpine ski operations $(16.2 \%)$, have considerably higher WC premiums. Table 4 presents a 'best guess' of industry-wide mandatory benefits in tourism and recreation.

The key implication of these approximations is that mandatory contributions add only about one-third as much to total labour costs in Maine as in Dalarna. Conceivably, voluntary employer contributions might make up much of the difference. Under federal and state law, employers are not required to underwrite health insurance, pensions, vacations, or medical and family leave. Although such benefits are fairly common among firms with over 500 employees, they are far less common among the small businesses typical of tourism. Indeed, if we focus on the most important employee benefit, health insurance, the proportion of small employers offering coverage is declining, as a cost-cutting reaction to fast escalating premiums (St John et al., 2000). The following data from a survey of Maine lodging and restaurant operators are the best available, although they are probably biased upward. ${ }^{8}$ (See Table 5).

It is difficult to assess the economic significance of voluntary benefits because the survey responses did not include monetary amounts; further, comparable information is lacking for the many other tourist services. America's big-ticket employee benefit is employer-subsidised health insurance, which adds as much as $5-7 \%$ to payroll costs. Considering the low frequency of employer subsidised health insurance and other benefits reported above, a reasonable upper bound estimate for all voluntary employer contributions is $5 \%$ of payroll, or $\$ 0.37$ /hour.

Combining information about wages, mandatory payments and voluntary contributions, we estimate that the average hourly labour cost in Maine tourism is in the neighbourhood of $\$ 8.64$ /hour (SEK 64.8), with $\$ 7.42$ in wages and $\$ 1.22$ in benefits. Benefits thus represent $16.5 \%$ of gross wages. In sum:

...Maine's average tourism wage is about the same as Dalarna's lowest wage $^{9}$ 
Table 5 Voluntary contributions by lodging and restaurant employers (\% of respondents providing the benefit to hourly workers in any amount)

\begin{tabular}{||l|c|c||}
\hline & Lodgings (\%) & Restaurants (\%) \\
\hline Contribution to health insurance & 34 & 27 \\
\hline Paid holidays & 25 & 32 \\
\hline Paid vacations & $19^{\text {a }}$ & $53^{\text {a }}$ \\
\hline Paid sick leave & 20 & 20 \\
\hline Free or subsidised meals & 46 & 98 \\
\hline Profit sharing or bonuses & 23 & 35 \\
\hline
\end{tabular}

a Typically applies only to full-time, year-round workers with at least one year of experience, and typically one week of paid vacation, increasing to two or three weeks after several years of service.

Source: Austin Associates, 1997 (unnumbered pages)

... Dalarna's average hourly compensation, including seasonal workers' supplemental vacation pay and unemployment compensation, is about $70 \%$ above Maine's; and

... Dalarna's average hourly labour cost is twice Maine's.

\section{Institutions affecting seasonal employment flexibility}

Under Maine law, employers with more than 100 workers must give 90 days notice prior to plant closings or mass layoffs. Large employers must also make severance payments to workers with three or more years seniority. These laws have no effect on the great majority of tourism sector firms and do not apply at all to seasonal employees. Employers have broad discretionary power to fire individual workers for cause. Although terminated employees can demand a written explanation for their firing, it is difficult and costly to win compensation or reinstatement through the legal appeals process (Murphy \& Hanson, 1995). In brief, there is practically no legal obstacle to terminating seasonal employees nor any penalty for laying off workers when tourist demand is slack. Of course, employers may have economic incentives to retain highly skilled workers through slack seasons and to take account of future recruitment and training costs when making layoff decisions. Particularly in Maine's south coastal region, with its low unemployment and year-round demand base, such considerations probably deter some layoffs.

On the labour supply side, few seasonal workers are eligible for unemployment compensation in Maine. Benefit levels are, in any case, low. In contrast to Sweden, where tourism workers have an incentive to apply for seasonal jobs because they qualify for unemployment compensation at $80 \%$ of past wages, America's tough UI eligibility criteria do not strengthen the incentives to seek seasonal employment, for example as ski lift operators, fishing guides, 'burger flippers', chambermaids, parking lot attendants, or whale watch crews.

\section{Hypotheses}

We hypothesise that tourism in Dalarna and Maine is affected in six specific ways by the labour laws and other institutions described above. 


\section{Hypothesis 1}

Maine's cheap labour and Sweden's expensive labour induce tourism service producers to adopt relatively labour-using production methods in Maine and relatively labour-saving methods in Dalarna. One crude indicator of this effect is that tourism (spending) accounts for roughly $4.4 \%$ of Dalarna's employment, versus $3.9 \%$ of gross county product, ${ }^{10}$ while Maine tourism accounts for $8.1 \%$ of employment versus $4.9 \%$ of gross product. Another way to describe the difference is that Maine tourism generates a full-time equivalent (FTE) job for each $\$ 64,100$ of tourist spending, while it takes $\$ 106,700$ of spending to create a FTE job in Dalarna. (Calculations based on official tourism employment and expenditure data: Longwood, 1997; LD, 1998; NUTEK, 1999.)

Corollary 1: Swedish tourism generates relatively high quality jobs, especially taking into account seasonal workers' health care coverage, supplemental vacation pay, and unemployment compensation eligibility.

Corollary 2: Maine tourism generates a large number of jobs, but the combination of labour laws and market forces results in low median wages, meagre benefits, and little unemployment compensation for less-skilled workers.

\section{Hypothesis 2}

Labour costs are a major determinant of many tourism service prices. For instance, labour accounts for 30\% of production cost in Swedish hotels and restaurants, compared to $15 \%$ in wood products and $12 \%$ agriculture and forestry and other major rural sectors (TD, 1996: 15). Maine tourists have a comparatively strong incentive to consume labour-intensive commercial services, while Dalarna tourists have a stronger incentive to substitute their own labour for purchased services. (This calculus is presented formally in the section below headed Sales and Excises Tax Wedges.) A crude example is the comparative prevalence of restaurant meals (in Maine): $24 \%$ of Maine tourist spending is at eating and drinking establishments, compared to $18 \%$ in Dalarna. The importance of this difference is suggested by the fact that, per krona of expenditure, restaurant meals create twice as much employment as food purchased at grocery stores and prepared by the tourist (Vail et al., 1998: 43; LD, 1998: 25). The senior author's 'participant observation' in both places suggests that table service is more common in Maine restaurants, while cafeteria and buffet service is more common in Dalarna.

\section{Hypothesis 3}

Labour laws and employment security measures tend to reinforce seasonal employment fluctuations in both places, but for different reasons. In Dalarna, seasonal workers' eligibility for unemployment compensation increases the supply of workers willing to accept non-permanent jobs and enhances employers' ability to hire and fire workers according to demand fluctuations. Working against that effect, several collective bargaining agreements exempt tourist businesses from the standard 40 hour workweek, and this tends to dampen seasonal fluctuation in jobs. Maine's highly seasonal tourism labour demand is reinforced by the lack of layoff restrictions or collective bargaining agreements protecting job security.

\section{Hypothesis 4}

Sweden's high cost per hour of labour drives up tourist service prices particularly for labour intensive services - putting Dalarna at a competitive 
disadvantage vis-à-vis lower-wage European destinations offering similar winter and summer attractions. In contrast, Maine's low service sector wages and labour costs give it a competitive advantage vis-à-vis nearby north-eastern regions with higher labour costs and similar tourist attractions (e.g. Cape Cod, upstate New York).

Corollary: The magnitudes of Maine's cheap labour advantage and Dalarna's disadvantage are not clear and should not be exaggerated. Impacts depend on numerous factors, including labour's share of total tourist trip costs, the accuracy of tourists' information about prices at competing destinations, and the 'cross elasticity of demand' for substitute destinations.

\section{Hypothesis 5}

Maine's cheap labour tourism tends to be self-perpetuating and contributes to socio-economic problems in some tourist-dependent communities. Jobs with low pay, few benefits, and no career prospects tend to attract less skilled and less motivated workers, reinforcing the low productivity/low wage syndrome. The social, cultural, and economic vitality of host communities may be sapped by a concentration of low paying, seasonal jobs that put local people in a quasi-servant relationship with high income visitors (Vail et al., 1998; Vail \& Hillard, 1997).

\section{Hypothesis 6}

Both Dalarna and Maine could achieve their tourism development goals more effectively if their labour market institutions converged toward a 'middle way,' reducing the cost of semi-skilled labour in Dalarna and raising wages and benefits in Maine.

Corollary 1: Sweden's 1995 law allowing year-round averaging of the 40 hour workweek is a step in the right direction, reducing employers'administrative costs and increasing the number of year-round tourism jobs.

Corollary 2: A state strategy to make 'livable wages' more widespread in Maine tourism would have three core components: more extensive training for front line tourism employees; measures to encourage the spread of 'high performance'workplace practices; and strengthening of labour market policies, including the minimum wage, the earned income tax credit, and unemployment insurance coverage for qualifiying seasonal workers (Vail \& Kavanaugh, 2000).

\section{Sales and Excise Tax Wedges: Effects on Costs, Competitiveness and Incentive}

Sales and excise taxes affect resource allocation and consumption, either for better or for worse, by widening the wedge between production costs and retail prices. The economic impact of such taxes depends on several factors, including the absolute tax rate, relative taxes on different goods and services, the producers' market power, and consumers' price responsiveness. Consumers' responsiveness to a commodity tax is reflected in demand elasticity, which is influenced by the strength of preferences for the taxed good, prices of substitute goods (substitution effect), the proportion of budgets spent on the good (income effect), 
and the length of time they have to adjust consumption in response to tax-induced price changes.

\section{Tax wedges and the tourist activity mix}

Many tourist 'products' can be characterised as composite goods that combine purchased goods and services with own-produced services. For example, driving to a nature reserve combines a car and fuel with the driver's labour; and preparing a campsite meal combines store-bought food, utensils, stove, etc. with the cook's labour. In these and many other activities, tourists face choices: commercial transportation versus self-chauffeuring, hotel versus tent, restaurant versus home cooked meal. Henrekson (1998) raises the question: what causes a certain activity to be performed in the taxed market sector, in the untaxed 'black market', or as self-production? Broadly, the choice can be viewed as tourists optimising subject to a budget constraint that includes both their time and money. Preferences and opportunity costs regarding leisure, wage earning work, and unpaid work all influence the outcome (Becker, 1968).

Even though tourists may not carry out an explicit calculus of monetary and opportunity costs, taxes can influence decisions whether to purchase or selfproduce services in two ways: directly via the value added tax (VAT) and indirectly via employers' 'pass-through' of mandatory contributions. In particular, even if commercial production of services is more efficient than tourists' self-production, the price inflating effect of these levies may induce self-production and depress tourism expenditures and employment. Påhlson (1997) has modelled the necessary conditions for a service to be bought on the market, when labour accounts for the major part of total costs. The consumer optimises by purchasing a service when:

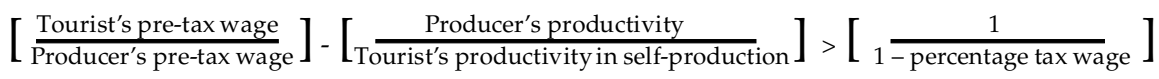

Intuitively, the incentive to purchase a tourist service rather than produce it for oneself is stronger: (1) The higher the tourist's wage rate relative to the producer's wage; (2) The lower the consumer's productivity relative to the commercial producer; and (3) The smaller the overall tax wedge.

In Sweden the ratio 1/(1 minus \%-tax wedge) lies in the range of 2.7 to 4.1 , while in USA the ratio is between 1.4 and 1.9. In other words, there is a much stronger incentive for self-production in Swedish tourism. In this rational actor framework, if productivity in commercial and own production were the same, a tourist's pre-tax wage rate would have to be at least 2.7 times greater than wages paid by the commercial producer to justify purchasing the service. Given Sweden's compressed wage structure, that is not the case for many tourists and services. (Because of lower US taxes, the American wage gap need only be $40 \%$ to warrant purchase of commercial tourist services; the gap between the average US wage and the typical tourism wages is much greater than in Sweden.) Conversely, if the tourist and producer had the same wages, commercial labour productivity would have to be at least 2.7 times greater than in self-production to justify purchasing a service (Henrekson, 1998). 


\section{Sweden's $25 \%$ value added tax and tourism}

In July 1990,Sweden's value added tax (VAT) was raised from $22 \%$ to $25 \%$ and Parliament eliminated special lower rates on parts of the travel and tourism industry. Thus the tax on restaurants, previously half the general rate, jumped to $25 \%$ and VAT was extended to previously exempted services including commercial transportation, commercial camp sites, ski lifts, and amusement parks. Apparently little consideration was given to likely competitive effects. ${ }^{11}$ Table 6 summarises Sweden's current VAT rates for core tourist services; they are substantially higher than the EU average. Compared to the other Nordic countries, with which Sweden competes most directly for foreign tourists, only Denmark's VATs approach Sweden's high levels on most tourism services.

A state-commissioned study showed that in the first two years of the new VAT rates, travel volume, tourism sector profitability, and employment all declined, while bankruptcies increased (NUTEK, 1993: 24). Hultkrantz (1995a) estimates that the VAT increases, combined with other tax revisions, reduced Swedes' internal recreational travel spending by at least $15 \% .{ }^{12}$ The tax increase also had significant substitution effects, with more Swedes vacationing at their own cottages, visiting friends and relatives, and travelling abroad. The higher VAT on commercial lodgings, restaurants, and other marketed tourism services raised their retail prices by $15 \%$ to $25 \%$, while the cost of visiting privately owned leisure homes was unchanged. Although it is difficult to separate the effects of a higher VAT from those of a contemporaneous national economic recession and exchange rate fluctuations, the evidence strongly suggests that domestic and foreign tourists are both price-responsive. The VAT increase led to fewer foreign visitors and more Swedes travelling abroad (TD, 1996: 14; Sahlberg, 1996). There have been no studies of the tax reform's specific effects on Dalarna tourism, but the overall impact must have been the same as for Sweden as a whole.

In sum, the higher VAT worked against commercial tourism by changing tourists' incentives in two key ways. First, the higher total cost of a Sweden vacation strengthened residents' and foreigners' incentive to travel elsewhere. Second, the tax increase strengthened incentives to substitute untaxed self-produced services for taxed commercial lodging, meals and entertainment. Data are not available to estimate demand elasticities for distinct tourism pack-

Table 6 Value added tax rates: Sweden and the EU

\begin{tabular}{||l|c|c||}
\hline \multicolumn{1}{|c|}{ Activity } & Sweden $(\%)$ & EU average (\%) \\
\hline General VAT & 25 & 19.3 \\
\hline Restaurants & 25 & 14.6 \\
\hline Car rentals & 25 & 18.7 \\
\hline Ski lift tickets & 25 & n.a. \\
\hline Amusement parks & 25 & 11.9 \\
\hline Hotels, hostels, campsites & 12 & 9.9 \\
\hline Commercial transport & 12 & 8.7 \\
\hline Theatres & 6 & 9.1 \\
\hline Museums & 0 & 4.5 \\
\hline \hline
\end{tabular}

Source: TD, 1996:18, 19 
ages (e.g. alpine ski holidays, heritage tourism, and fishing) or to estimate the cross-elasticity of demand for commercial vs. self-produced services. National time series data show the expected inverse price-quantity relationship in foreigners' recreational travel to Sweden; however, microeconomic analysis reveals a complex pattern of price responses. For example, Danes and Germans visiting Sweden to enjoy nature are not very price sensitive, in contrast to Norwegians and Finns, who arguably can opt for close substitutes at home (Nordström, 1999).

In the most intensely competitive parts of Dalarna's tourism industry, for instance lodgings in the Siljan region, both tourist numbers and the after-tax price received by producers are depressed by high taxes. Lower profit margins and employment in the short run and lower investment over the long term are plausible consequences of depressed operating revenues. While Sweden's high VAT may depress after-tax income and employment in Dalarna, the added tax revenue from foreign tourists is a benefit from the national perspective. Particularly if foreign demand for the internal components of Swedish holidays were less than unitary elastic, the higher prices stemming from Sweden's high VAT would increase national tourist earnings. This may well be the case for Dalarna, where unique natural and cultural features make it a special tourist destination. Similar issues are under discussion in Australia, which is considering alternative tourism development strategies (Clarke, 1997).

\section{Vehicle fuel taxes}

Sweden has among the world's highest excise taxes and retail prices for personal vehicle fuel. The current tax of SEK 5.54/litre (\$0.74) represents $59 \%$ of the February 2000 pump price for low octane gasoline. ${ }^{13}$ High fuel taxes and a low $12 \%$ VAT on commercial transportation probably induces some tourists to opt for commercial transportation and reduces total travel to some remote northwestern Dalarna destinations. These effects are not likely to be large, however, since fuel cost is just a small fraction of the total holiday trip price. The fact that $90 \%$ of Dalarna's visitors arrive by car, despite excellent train and bus service, reflects a strong preference for the flexibility and convenience of automobile travel (Nerhagen, 1997: 7).

\section{Maine's low taxes on tourism services}

The United States has no general sales or value added tax, but roughly $30 \%$ of Maine's \$3 billion/year in state and local revenue comes from a 5.5\% retail sales tax. Like many other states, Maine imposes a higher tax (currently 7\%) on meals at expensive restaurants and commercial lodgings, which cater largely to tourists. The $10 \%$ car rental tax affects primarily tourists and business travellers. In contrast with these tax surcharges, amusement and recreation services are completely exempt from sales tax, as are basic groceries. Maine's sales tax is in line with all but one of the neighbouring New England states and lower than nearby Canadian provinces. ${ }^{14}$ In sum, compared to Sweden, Maine's sales tax adds relatively little to the total cost of a tourist visit and presumably has less influence on the incentive to self-produce services.

It is estimated that tourist spending directly generated $\$ 206$ million in state tax revenues in 1996, with $\$ 118$ million coming from sales and excise taxes and \$27 
million from the gasoline tax (Longwoods Associates, 1997: 25). Systematic records are not kept on the other side of the fiscal ledger: the state and local government spending required to support the tourist economy (e.g. road maintenance, water supply systems, waste disposal, police, fire and hospital services). Maine municipalities cannot levy their own sales taxes to capture part of the tourist revenue stream or cover the cost of public services that underwrite commercial tourism. A previous study indicated that Maine could (and should) raise an additional $\$ 26$ million in sales taxes targeted to tourist spending, on the principle that visitors should pay for the public services they require and for the environmental wear and tear they cause. That goal could be accomplished by raising the restaurant and lodging taxes another $1 \%$, adding $1 \%$ to the sales tax on recreational equipment, and extending the sales tax to amusements and recreational services. Tourist demand is predicted to be highly inelastic over such small retail price increases, thus tourist spending would be only minimally affected and the tax incidence would be borne primarily by visitors (Vail et al., 1998: 74-5).

At present, low octane ('regular') gasoline is priced at about $\$ 1.50$ /gallon in Maine (SEK 2.1/litre), or about one-fourth of the Swedish price. Perhaps this enormous differential reflects in part the northeast US' more intense retail competition and lower refining and fuel transport costs, compared to Sweden. However, the big difference is that state and federal excise taxes $-\$ 0.37 /$ gallon (SEK 0.64/litre) - are only about one-tenth of Sweden's. Recent proposals for significant federal and state gasoline tax increases - whether to generate revenue, induce energy conservation, improve ambient air quality, or cut greenhouse gas emissions - have met with intense resistance from motorists as well as the powerful petroleum-automobile-highway construction lobby. The regressivity of the gasoline tax and Americans' almost total dependence on cars, trucks, vans, and sport utility vehicles for commuting, shopping and leisure activities make cheap gasoline a 'knee jerk' populist issue. Despite several legislative attempts, Maine's gasoline tax has not been increased since 1991. Late in 1998, following his landslide re-election, Maine's governor proposed a modest $\$ 0.05 /$ gallon (SEK $0.10 /$ litre) tax increase, with the revenues dedicated to a backlog of urgent road and bridge repair needs. Despite the minimal increase and the widely recognised need for better road maintenance, the legislature enacted only a $\$ 0.03$ increase.

\section{Hypotheses regarding the impact of sales and excise taxes on tourism}

\section{Hypothesis 1}

Sweden's high tax on most tourism services has a significant depressing effect on the number of foreign and Swedish visitors to Dalarna as well as their contribution to the region's economy. In general, consumer demand seems to be elastic over price increase caused by the tax; however, demand effects vary for different activities and tourist groups. The decline in tourist numbers is mitigated somewhat by more tourists who substitute cheaper self-produced services for more expensive taxed services. Maine's much lower retail sales taxes add comparatively little to total trip costs and are in line with competing states; thus they have little effect on tourist numbers, total expenditures, or the composition of spending. 
Corollary: Maine could incrementally increase sales taxes on lodging, amusements and recreational equipment purchases without significant adverse effects on tourist numbers or total spending. In other words, consumer demand is inelastic over small increases in total trip cost. The added tax revenues would enable the state to cover public expenditures for tourist infrastructures and services and help pay for protecting prime natural attractions.

\section{Hypothesis 2}

Dalarna's high VAT on most tourist services, combined with high labour costs, encourages tourists to self-produce services instead of purchasing labour-intensive commercial services. The latter would contribute substantially more to regional production and employment.

Corollary: Sweden's high VAT strengthens the incentive of tourists and businesses to engage in untaxed black market transactions for services like cottage and campsite rentals and sporting guides.

\section{Hypothesis 3}

Sweden's low VAT on theatres (6\%) and museums ( $0 \%$ ) and Maine's sales tax exemption on 'amusements and recreation' have the beneficial effect of encouraging tourist spending on these value-added and culturally enriching activities. No more than $10 \%$ to $14 \%$ of total tourist spending is currently channelled to such activities, so these low tax rates help boost demand in an under-developed - and relatively labour-intensive - part of the tourism economy (See Appendix 1).

\section{Hypothesis 4}

Maine's comparatively low taxed and cheap gasoline encourages more day and weekend visits, focusing on activities like 'sun and surf', outlet mall shopping, skiing, and fall 'leaf peeping'. At a time when leisure travel is increasingly compressed into short holidays, this may give a destination like Maine a significant competitive advantage in its market.

Corollary: The extreme car-dependence of tourism in both places raises sustainable development questions: it intensifies peak period traffic congestion and increases ambient air pollution and greenhouse gas emissions per visitor.

\section{Land Ownership and Property Rights: Recreational Access to Private and Public Land}

The forests, mountains, lakes and rivers of Dalarna and Maine are prime tourist attractions. According to one set of estimates, nature-based tourism in and around Maine's 4 million hectare North Woods accounts for nearly \$1 billion/year in gross tourist spending (including dining, lodging, shopping and transportation) (MAS, 1996). Even for tourists attracted primarily by cultural events, shopping, or just relaxing, beautiful natural settings comprise the backdrop for Dalarna and Maine vacations. In economic terms, recreational landscapes are best understood as impure public goods with limited exclusion possibilities and a degree of rivalness in use.

Dalarna and Maine are similar in that most land is privately owned (Dalarna 75\%; Maine 94\%) and is working forest, not only a recreational resource. Outdoor recreation in a multi-function ecosystem coexists with and 
affects other recreation, non-recreational land uses, and basic ecosystem functions. For example, snowmobiling, a popular winter-spring activity in Dalarna's mountains, affects cross-country skiing, commercial forest management, Sami reindeer herding, and critical habitat for fish, fowl and mammals.

Within these similarities, institutional differences influence nature tourism's economic potential and environmental sustainability. In Dalarna the right of common access to private land (allemansrätten) and small fragmented land holdings are key contextual features. In Maine's North Woods there is a a prevalence of large industrial land ownerships combined with a tradition of 'permissive access'. This section explores how these and other property institutions affect landowners' and tourists' incentives and create pressure on ecosystem carrying capacity.

\section{Open access, fragmented ownership, and development of nature tourism in Dalarna}

Most of Dalarna's undeveloped land is held in 24,000 private ownership's, although a national park and almost 100 nature reserves cover $8 \%$ of forest land. Some of the latter parcels, especially in the mountains, are important for tourism. For instance, one nature reserve embraces Sweden's highest waterfall, Njupeskär. There are also three large industrial forest owners which together hold almost $50 \%$ of Dalarna's land area. Municipalities, the Church of Sweden and the Dalarna County Board are other minor landowners (SCB, 1999).

Fragmented ownership characterises the county's more densely settled regions. The Lake Siljan region has the most fragmented land holdings in Europe. It was one of few areas exempted from Sweden's major land partitioning in late 18th and early 19 th centuries. Narrow strip holdings, a metre or two wide but several kilometres long, are common (Westholm, 1992). In the past, this was a problem primarily for forestry operations, but recently it has also emerged as an obstacle to commercial tourism development. A major recreation park was delayed several years because so many landowners were involved; and the combination of fragmentation and open access has impeded commercial beach and marina development. In the mountains, property rights and land use controversies surround the expansion of alpine ski areas, use of motorised recreational vehicles, Sami people's usufruct rights, and environmental damage in fragile alpine zones subject to the combined impact of recreation, industrial forestry and reindeer herding.

\section{The problematic side of allemansrätten - Sweden's right of common access}

As a matter of principle, access to outdoor recreational opportunities is open and free in Sweden. The right of common access rests on the implicit but incorrect presumption that recreational landscapes are pure public goods. Allemansrätten is not explicitly defined in law; ${ }^{15}$ rather, it is a set of customary rules and judicial decisions governing activities not mentioned in laws articulating the state's obligation to defend landowner claims. These use rights have been preserved from archaic law, so in a sense current rights still reflect relative resource scarcities and prices from the 13th century. Over the centuries, some valuable species have become scarcer (e.g. chanterelle mushrooms and cloudberries), yet they have 
remained free to everyone, as do distinctly modern attractions like white water streams and snowmobile trails. Allemansrätten has roots in a custom allowing free travel in roadless country, including the right to stay overnight and collect natural products to eat and drink. Today, this custom allows recreational trespass and primitive camping on private land. However, allemansrätten also entails an ethical responsibility to avoid harm to nature or economic damage to the owner, for instance to crops and timber stands (Colby, 1988).

Allemansrätten has nearly universal public support and has been used to rationalise the extension of rights well beyond its traditional domain, particularly in sport fishing and snowmobiling. This includes situations where open access conflicts with efficient resource use, rights of aboriginal Sami people, and interests of other recreationists. A national recreation policy based on open access is not fully compatible with a rural development strategy based on promoting commercial tourism. In sum, compared to Maine, Dalarna's nature tourism is growing in conditions less friendly to commercial exploitation of nature. Alpine skiing is the key exception for complex reasons, but especially because a natural force - gravity - makes it easy to exclude free riders by charging for lift tickets (Vail \& Hultkrantz, 2000).

Swedish citizens, foreign tourists, and even commercial tourist businesses have the right to use private property for recreation without paying user fees. Nonetheless, this right falls short of true 'open access', since certain activities are prohibited (e.g. hunting, fishing, felling trees, disturbing wildlife habitat) as is trespassing on certain lands (e.g. cropped fields, homesteads). Privately owned landscapes thus resemble, but are not identical to, open access common pool resources. The following examples are stylised (deliberately one-sided) to highlight problems that arise in this institutional setting.

The lack of mechanisms to exclude recreational users or secure payment for nature's - and landowners'- services has caused two familiar common pool resource problems: short-term congestion and long-term resource depletion. Snowmobiling in Dalarna's mountain region is a prime example. At the Easter weekend peak, snowmobiles may congest popular trails to the point of causing traffic slowdowns, increased accidents, and degraded air quality. These 'reciprocal externalities' reduce amenities to all snowmobilers. Snowmobile traffic is also experienced as a 'unidirectional externality' by other recreationists, particularly cross-country skiers. Unregulated snowmobiling may impede non-recreational activities, such as Sami reindeer herding and logging operations. In fragile environments, unregulated snowmobiling may also have detrimental long-term effects, for example, disrupting bird and mammal breeding, depleting fish stocks (via ice fishing), and destroying young tree seedlings (Anttila, 1999; Hultkrantz, 1995b).

The development of instruments for pricing recreational land use must be compatible with allemansrätten but take advantage of its limitations. First, free access applies only to individual recreationists; second, as mentioned, fishing and hunting rights are not included. In principle, allemansrätten does not apply to organised commercial recreation, which should open the possibility of charging for some land uses. To date, contractual landowner compensation has only occurred in a few circumstances, such as military manoeuvres and large-scale sporting events. The National Farmers' Association (LRF), which represents 
thousands of small Dalarna landowners, has pressed the issue by initiating litigation to win compensation for organised tourist activities on members' land. The courts have thus far gone against landowners, ruling that tourists should have free access as individuals even when they participate in commercial activities like guided backpacking and mushroom-picking tours.

The open access tradition, backed by the court's ruling, weakens owners' incentives to invest in land stewardship and some types of value-added capital: they cannot recoup the expense of efforts like trail maintenance and river bank erosion control. Even where fee collection is legal, for instance at picnic sites and canoe put-ins, there are practical difficulties in recouping investments, such as monitoring and fee collection costs. (Note that these particular costs would not disappear with public land ownership.) In short, tourists' ability to free ride on landowners' investments mis-aligns incentives in ways that are bad for both the environment and the local economy. When owners' and users' incentives conflict with their sense of moral obligation, it is unwise to rely exclusively on 'voluntarism,' as allemansrätten does. Ski lift tickets and fishing licences are two means currently used to align landowners' and tourists' incentives. Guided tours with a fixed 'package price', for instance fishing and cross-country skiing tours, are another potential way to extract economic rent for use of nature's services.

\section{Scale misalignment between small landholdings and large efficient management units}

Fragmentation makes it difficult for landowners to capture potential economies of scale in tourism investments. Three examples are: (1) economies in building and maintaining physical infrastructures, such as road and cross-country ski trail networks that cross property lines; (2) development of tourism destination 'packages' that combine parking areas, cabins, cafés, and boat launches on different properties; and (3) lower transaction costs for promotion, fee collection, and monitoring. These latent opportunities are an incentive for collective action by landowners, an approach with many precedents in rural Sweden. Fish conservation districts (fiskevårdsområden), are an example, whereby riparian owners sell fishing licences to control access and capture rent.

On a much larger scale, investors in the Sälen and Idre ski resorts coordinate promotion, local transportation, fee setting, and social events. And the State Forest Management Company (Assi Domän), although a single large owner, follows an integrated back country recreation management strategy. In sum, collective action has the potential to be a 'win-win-win' game, where landowners, the local economy, and the environment all benefit. Joint resource management institutions face internal governance problems, however, and success is not guaranteed.

\section{Idre/Grövelsjön: a mini-case study}

To highlight the problems and potential associated with property rights, scale economies, and rent-capturing initiatives, we sketch the evolution of outdoor tourism in Idre/Grövelsjön, in Dalarna's far northwestern corner (see map Figure 1, Appendix 2). More than a century ago, Arthur Hazelius set the stage for Dalarna tourism by founding Stockholm's Skansen, the world's first 'outdoor-life'-museum, which celebrated Dalecarlian folk culture. The fledgling 
Swedish Tourism Association (STF) helped spread knowledge of Sweden's varied regional landscapes and local cultures. In 1907 Dalarna's first year-round hotel with its own 'touristlift' was advertised. By 1937 the 'Högfjällshotel' in Sälen and STF's mountain station in Grövelsjön were in operation.

Grövelsjö tourism was and remains dominated by small family owned hotels with XC skiers and hikers as the main guests. But nearby Idre municipality has developed a large alpine skiing resort presided over by the Idre Fjäll (IF) corporation as an outgrowth of the late-1970s alpine skiing boom. It owns or controls a large area around the main mountain, Grängesvålen, which hosts more than 30 ski runs, $60 \mathrm{~km}$ of XC tracks and hundreds of rental cottages (Idre Fjäll, 1999). By controlling core economic facilities over a sizable area, IF can employ both direct and indirect means to appropriate land rents. Compared to most other nature-based recreation, alpine skiing has a more straightforward way to charge users via lift tickets. Land rents can also be appropriated indirectly through oligopoly pricing of the complementary services and accommodations that make up a ski holiday package. A part from alpine skiing areas, however, there is not much scope for exercising such market power in Dalarna. For instance, the lodging sector in most of the county is highly competitive and suffers from excess capacity.

XC-skiing, like most nature tourism, lacks a direct mechanism to charge for use of nature or for costs borne by landowners. Under allemansrätten, fees cannot normally be charged for entrance to undeveloped areas, whether private or public. Thus a landowner's costs for laying out and maintaining a ski track or thinning timber stands to improve aesthetic quality can only be captured via the price of lodging or a complementary service like ski equipment rental and ski instruction, which may not be supplied by the landowner. Introducing user fees might seem an easy way to overcome the problem, but there are several limits to fee collection. Permission to fence a recreational area and charge fees requires that the owner 'develop' the area by constructing facilities that seriously disturb natural features, as in the case of a golf course or recreation park. Moreover, commercial facilities such as campsites, fishing and bathing piers, toilets and parking lots, cannot be provided exclusively to one group of users, such as a tour operator's paying clients (Vail \& Hultkrantz, 2000).

In Grövelsjön, with its family hotels, rental cottages, and STF mountain station, family traditions are strong and tourist operations are small scale compared to Idre Fjäll. Winter season is dominated by XC-skiers seeking silence along mountain tracks in the semi-wilderness surrounding Lake Grövlan. Snowmobilers also drive to mountain lakes for ice fishing, and a few alpine skiers use the two 'single-lift' establishments. This small business profile has made achievement of scale economies in service provision difficult, although there is cooperation in marketing and promotion. Land holdings are not as small as around Lake Siljan, but fragmented ownership problems are present. To overcome open access problems and achieve scale economies in building and maintaining the $\mathrm{XC}$ ski network, tourist business operators and surrounding private cottage owners have formed a 'track making' association. The businesses make and groom the trails while cottage owners pay a yearly fee to the association and benefit by being able to charge vacationers higher rents. Without the trail network, there would be few winter tourists. The rights issue of a commercial 
track crossing numerous private holdings is solved by simple contracts with landowners. The association has just a small budget to compensate them, and what makes the trail network economically viable is its indirect value in attracting tourists and their spending to the area. Voices have been raised for introduction of a direct 'ski fee' that would include a contribution to local nature conservation efforts (Westergård, 1999).

In contrast to Grövelsjön, Idre Fjäll controls the land in its XC-ski network and faces no multi-owner conflicts. It charges SEK 50 (\$6.60) per day for use of its trails; for visitors staying in IF lodgings, the fee is included in the room or cottage fee. IF is concerned about the free-rider problem of non-paying visitors, mostly local residents, using the illuminated and well groomed tracks; but for cultural and aesthetic reasons it has chosen not to fence the trails or gate the entrance (Idre Fjäll, 1999).

\section{Residents' rights, land ethics, and farsighted stewardship}

Dalarna's ambition to expand nature tourism raises an equity issue: the restriction of local residents' customary land use entitlements. More visiting hunters, fishers, campers and snowmobilers adversely affect their well-being. Traditionally, the rural landscape was both their playground for active and contemplative recreation and a source of subsistence via hunting and gathering. The right of common access does not protect residents' quality of recreational experience or compensate for amenity losses when they are 'crowded out' by tourists. The Swedish Tourist Authority foresees a related danger that visitors, especially foreigners, will lack environmental understanding and a sense of responsibility for nature protection. In short, tourism growth may erode the land ethic that made allemansrätten 'work' in the past (TD, 1998b: 44).

Finally, nature tourism promotion is not backed by a comprehensive natural resource inventory, local carrying capacity estimates, or a long-term resource management plan. This institutional deficiency has already had conspicuous effects such as fish stock depletion in high altitude lakes, degradation of thin mountain valley soils, and disruption of wildlife breeding. (Unregulated snowmobiling is implicated in all of these.) An overarching analysis of ecosystem carrying capacities and a land use management plan would help to resolve the two property rights conflicts that have generated most heat in Dalarna: proposed expansion of the Sälen-Idre ski area into the Städjan National Park, and the Sami people's rights to herd reindeer, hunt, fish and harvest timber. A more thorough analysis and forecast of the demand for Dalarna's various natural attractions would also facilitate more effective resource management and tourism promotion.

\section{Commercialising outdoor recreation in Maine's North Woods}

Maine's 94\% private land ownership ranks it near the top among US states. Over $90 \%$ of surface area is forested and most is industrial forest. Much outdoor recreation makes use of private land, as Table 7 reveals. In addition to the listed activities, almost all hunting and alpine skiing take place on private land.

Public lands, though not extensive, are also important for tourism and recreation. Federal lands, Acadia National Park and a section of the White Mountains National Forest, host five million yearly visitors. The $150 \mathrm{~km}$ long Allagash Wilderness Waterway is the only federally designated wilderness east of the 
Table 7 Proportion of Maine's recreational activity on private land (1992)

\begin{tabular}{||l|l||}
\hline White water rafting & $100 \%$ (put in and take out sites) \\
\hline Trail biking & $98 \%$ \\
\hline Camp sites & $98 \%$ (many maintained by Maine Forest Service) \\
\hline Snowmobiling & $67 \%$ \\
\hline Hiking & $60 \%$ \\
\hline XC skiing & $59 \%$ \\
\hline
\end{tabular}

Source: Irland, 1993: 10

Mississippi River. There are also 61 parcels of state lands, and thousands of lakes and ponds are held in public trust by the state. The jewel in the crown is the 80,000 hectare Baxter State Park in the heart of the North Woods, with 1600 metre Mt Katahdin marking the northern end of the $3000 \mathrm{~km}$ Appalachian Trail (see map Figure 2, Appendix 2). Many of Maine's 464 towns and cities also have public parks and commons, beaches and boat landings. Finally, a small but growing area of ecologically and recreationally valuable land is being acquired by land trusts and conservation organisations.

Almost all of the 4 million hectare North Woods are held by about 15 large owners. By custom, though not in law, there has been 'free and easy' recreational access to most of this land going back to H. D. Thoreau's first visit in the 1840s. In this century, paper corporations with familiar names like International Paper and Boise Cascade have been the dominant owners and a powerful presence in Maine's economy and politics. However, in recent years the number and composition of forest land owners have been in flux, with paper corporations consolidating, selling, or developing timberland as part of worldwide asset management strategies.

Recreational land use is legally governed by a system of 'permissive access', whereby owners can prohibit access or charge fees. Prospective users have a nominal obligation to seek permission. In practice, however, hunters, fishers, hikers and other recreationists have faced few restrictions or fees. As late as 1982, only $8 \%$ of Maine's undeveloped land was posted against trespassing (Irland, 1996: 61). Recreational users have extensive rights to cross forested or unfenced land to reach lakes and large ponds. Rivers and 'floatable' streams are also open to the public, though there is no general right of trespass to reach them. Trees and other vegetation belong exclusively to the owner, while fish and game are a 'public trust', requiring only a state licence (Hasbrouke, 1988). These property rights obviously differ in important ways from Sweden's allemansrätten.

Over time, recreationists and sporting organisations came to view access as a de facto right. This is reflected in the fact that the Inland Fisheries and Wildlife Department (IFW) has a 'landowner relations coordinator' who mediates owner-user relations and educates sportsmen about their responsibilities: 'Everyone MUST respect all landowners and their rights... All landowner wishes have to be followed by all outdoor recreational participants to help ensure access to private property in the years to come' (IFW, 1998b). State agencies promote a 'public-private partnership' in many ways. For example, IFW facilitates contractual negotiations between landowners and snowmobile clubs over trail layout and maintenance; the Maine Forest Service maintains nearly 100 campsites on 
private land; the Department of Conservation coordinates dam releases for whitewater rafting; and a 1978 law strictly limits the liability of landowners who allow free access (ALT, 1996; Hasbrouke, 1988; IFW, 1998a; Irland, 1993).

\section{Contested terrain}

For most of this century, permissive access enabled recreationists to use vast stretches of undeveloped private land for hunting, fishing, canoeing, etc. In general, recreational use levels were compatible with the forest owners' timber management goals. In fact, free access helped them maintain the goodwill of politically influential groups at little opportunity cost. Over the past quarter century, however, a complex set of changes has induced many owners to restrict access, charge user fees, develop prime shore front real estate, and liquidate forest holdings. These trends accelerated in the latter 1990s, leaving the future of nature-based tourism in doubt. The major factors changing landowners' costs and incentives can be catalogued as follows:

... expanded timber harvesting, mechanised logging, and herbicide spraying brought industrial forest management into greater conflict with recreational uses;

... construction of nearly $40,000 \mathrm{~km}$ of logging roads brought once remote areas within reach of motorised vehicles;

...noisier and more intrusive recreational vehicles (sport utility vehicles, all-terrain vehicles, snowmobiles, jet skis, and even light planes) became common;

... tourism promotions informed a broader public about the North Woods' recreational 'gems' and brought visitors who lacked the traditional users' land ethic;

... a nationwide shift toward concentrated day, weekend and holiday trips intensified peak congestion pressures;

... wear and tear on infrastructures, waste disposal costs, fire hazards, and vandalism increased;

... the market value of undeveloped land for seasonal homes escalated, especially on lakes and ponds and near alpine ski areas, reflecting consumers' growing wealth and easier access.

The paper corporations' strategic perspective on forest holdings has also evolved. Forest land formerly viewed as a raw material 'mine', an illiquid asset, and a cost centre is increasingly considered a multiple use resource, a liquid asset, and a profit centre. This shift is part of the industry's globalisation and restructuring, driven by shareholder demands for higher, faster returns on investment (Irland, 1996: 41). Together, these changes have brought about four landowner and government reactions that are sketched here: gating the North Woods and collective management by large landowners; cumulative, irreversible real estate development; reactive land use regulation; and public acquisition of land. (For a more thorough discussion, see Vail \& Hultkrantz, 2000.)

\section{Gating and cooperative management}

Commercialised recreation has a long history in Maine's North Woods, with alpine ski areas in existence for decades and commercial sporting camps for 
more than a century. Since the 1970s, forest owners have also contracted with white water rafting outfitters for base camps, take-out places, and water releases from company-owned dams. In 1998, 81,000 tourists took commercial rafting trips (AP, 1998). Nonetheless, the past two decades mark the first period when large owners have gated private roads into their holdings, excluded some users (e.g. all terrain vehicles), and set up check points to collect fees from users. A positive result of gating is that it increases landowners' ability to control congestion pressures at peak sites and times and reduce conflicts between recreation and timber management. New revenue earning opportunities also strengthen owners' incentives to practise land stewardship and invest in value-added facilities, such as campsites, cabins and boat launches. On the other hand, the equity of gating and fee collection can be questioned, since traditional user groups have lost their free access entitlement.

In 1971, 24 owners of 1.2 million hectares, mostly remote wildlands in northwest Maine, formed a non-profit corporation, North Maine Woods, Inc. (NMW), to manage recreational activity. NMW collects day fees and campsite fees from roughly 200,000 yearly users and manages nearly 1000 campsites as well as parking lots, boat launches, and waste disposal systems. Landowner cooperation includes liability insurance, road maintenance, fish stocking, legislative lobbying, and contracting with sporting organisations. The latter activity has features of a repeated cooperative game. For instance, NMW contracts with the Maine Snowmobilers Association over the layout and maintenance of a $100 \mathrm{~km}$ section of a major US-Canada trail network. Snowmobile club members have assured access to trails, campfire sites, and ice fishing ponds for a modest annual fee of $\$ 25$. In return, the clubs maintain trails and enforce basic 'rules of the road', especially keeping to marked trails, avoiding logging operations, and preventing drunk driving (Cowperthwaite, 1999; Fisk, 1999;Irland, 1993:8-9). The IFW facilitates contract negotiations and allocates a share of snowmobile license fees to trail maintenance.

Through joint land use management, NMW's members achieve economies of scale with infrastructures and cut the transaction costs of promotion, gating, monitoring, and fee collection. Contracts with sporting groups appear to be a 'win-win' arrangement, with users gaining stable, low cost access and the owners benefiting from the users' self-policing. Government agencies, trusted by both sides, play an important brokering role.

\section{Cumulative and irreversible real estate development}

Maine's North Woods are in the midst of a real estate boom that combines two processes: accelerated turnover of paper corporation land and expanded seasonal home construction. The Land Use Regulation Commission (LURC), which regulates land use in Maine's 'unorganised territories', believes that, 'Cumulatively, second home development may have the greatest impact on natural and recreational resources in the region' (LURC, 1997: 67-8). The extent of home building is not known precisely, but a government official estimated in the early 1990s that 1000 cabins had been built 'in recent years'. Hundreds of existing structures are being enlarged and winterised (Irland, 1993). This is most intense in the west-central mountain and lake region, near ski resorts and on lake fronts that are within an easy day's drive of metropolitan Boston. Lease fees for 
many corporate-owned cabin sites have increased by $1000 \%$ in recent years, reflecting soaring consumer wealth. Several industrial landowners are 'cashing in' by selling off formerly leased cabins (Fisk, 1999).

Each hectare of wildlands converted to leisure home lots has a 'shadow conversion' effect on several more hectares, as access roads and drainage ditches are built, electricity lines are installed, 'NO TRESPASSING' signs appear, roads are gated, and game corridors are disrupted. The solitude of an entire lake can be destroyed by one jet ski speeding across its surface and one brightly lighted home on its shore (Irland, 1993).

For decades, paper corporations have bought and sold forest land, but the process has accelerated and a new type of ind ustrial landowner has appeared. A noteworthy sequence began in 1994, when Scott Paper sold its Maine paper mills and 400,000 hectares of forest, including parcels of tremendous scenic, recreational and ecological importance, to SAPPI (South African Pulp and Paper). In 1998, SAPPI re-sold the lands to Plum Creek Timber, a western US land development company with a reputation for 'liquidation' clearcutting and speculative land sub-division. Although Plum Creek has contracted to supply pulpwood to SAPPI's mills, it has also created a 'real estate development trust' to oversee commercial land development. The same year, Bowater Inc. sold a million hectares-Maine's largest single holding - containing prime recreational lands it had purchased just a few years earlier. About half of the parcel was sold to another out-of-state land management company. Finally, a few months later, Georgia Pacific sold 175,000 hectares to an anonymous institutional investor. All told, more than $30 \%$ of Maine's North Woods and 15\% of the state's entire land area changed hands in 1998 and early 1999; still more land is on the market. The new owners are a mix of mill-owning corporations and real estate developers plus family and institutional investors with reputations for 'patient capital'. However, the growing presence of land speculators and developers and the irreversible impacts of real estate development all bode ill for the future of back country nature tourism (Austin, 1997b).

\section{Inchoate political responses: Increased regulation and public ownership}

North Woods land use is nominally guided by the Land Use Regulation Commission's 1997 Comprehensive Land Use Plan. However, LURC's ability to prevent real estate developments that undermine sustainable tourism is limited by numerous factors, including landowners' rights, Maine's prevailing ideology, limited information, the economic interests of politically appointed commissioners, and pressures from various interest groups. It is thus not surprising that LURC's responses to development pressure have not followed a 'comprehensive plan', but rather have been reactive and piecemeal. Nonetheless, the LURC staff's critical appraisal of the situation has led to new growth management initiatives based on two principles: first, channel intensive seasonal home building and high volume tourism away from inappropriate areas and into 'areas most appropriate for development'; second, apply more stringent zoning criteria to sub-divisions and major developments (LURC, 1997).

LURC is in the process of identifying 'Recreation Protection Subdistricts' that 'support or have opportunities for significant primitive recreational activities' and adding zoning restrictions to prevent incompatible development. In 
principle, 'All new development must meet the requirement that "provision be made for fitting the project harmoniously into the existing natural environment in order to assure that there will be no undue adverse effect on existing uses, scenic character and natural and historical resources"' (LURC, 1997: 148). In practice, the commissioners face twin dilemmas: 'Seasonal housing development is most likely to occur in areas with high recreational values', and landowners' rights often supersede zoning criteria.

Recently, LURC resisted pressure from a powerful sportsmen's organisation by rejecting a boat ramp on an undeveloped lake. It has also refused permission for a commercial sporting camp complex on several remote ponds (Austin, 1997a; Fisk, 1999). However, the Commission admits that its current standards contain few firm and specific guidelines, which strengthens land owners' ability to avoid or appeal decisions they do not like (LURC, 1997: 148). In sum, LURC lacks the authority, facts, and personnel to manage North Woods development according to a true 'comprehensive plan'. In the past, even when the pace of land conversion was slow, LURC's actions tended to lag behind trends on the ground. In the future, the Commission's capacity may be overwhelmed by accelerated land use conversion.

The past decade has been marked by political struggles over property rights in the North Woods, though for most of the period forest management practices, rather than recreation and nature conservation, were the central issues. Ten years ago, Maine voters passed a referendum to invest \$35 million in 'Land for Maine's Future', but priority was given to protecting land under development pressure in more populous regions, especially on and near the coast. Only one sizeable North Woods tract (11,000 ha) was acquired. The momentum for additional public purchases was slowed for several years by a split between two conservationist factions, one advocating selective purchase of parcels with special scenic, recreational, biological and watershed protection values, and the other proposing a contiguous Maine Woods National Park of $c .1$ million hectares. Both approaches are ambitious by any historical standard and would require federal funding to complement state bond revenues. ${ }^{16}$ Both are also opposed by right-wing property rights activists (the so-called 'wise use' movement) and viewed sceptically by paper corporations that fear a loss of working forest.

Public anxiety was aroused by the massive 1998-99 land sales and the prospect of losing still more wildlands through gating, liquidation timber harvesting, and seasonal home construction. In November 1999, Maine voters approved a second Land for Maine's Future bond, this time for $\$ 50$ million, with good prospects for at least $\$ 25$ million in local and federal matching funds. The state has already purchased a 200 metre wide 'beauty strip' from Plum Creek Timber, protecting over $100 \mathrm{~km}$ of prime lake and river frontage and widening the Appalachian Trail corridor. (The state has power of eminent domain to acquire private land at 'fair value', but in practice, all public purchases have been on a 'willing seller-willing buyer' basis.) Important acquisitions by two conservation groups actually preceded the state's action. In the fall of 1998, The Nature Conservancy paid International Paper $\$ 35$ million for 80,000 hectares of remote forest land on the US-Quebec border, including important wild rivers and several 1200 metre peaks. Recreational uses will be managed by North Woods, Inc. In March 1999, the New England Forestry Foundation contracted for a \$30 million conservation 
easement that will prevent real estate development and sustain a mix of forestry and recreation on 300,000 hectares of land owned by the heirs of a 19th century 'timber baron'.

In the meantime, Maine's Bureau of Parks and Lands has moved toward a more rational, multi-tier fee structure for the state parks: at peak seasons, fees are higher at several congested sites, and lower for Maine citizens, recognising their implicit property right. Part of the added revenues will be earmarked for natural resource protection and restoration (BPL, 1998). These actions are not anything like a coherent land use strategy for the North Woods. Maine is just in the early stages of designing a plan that would fulfil politicians' rhetorical commitment to sustainable multiple use resource management.

\section{Hypotheses regarding property rights institutions}

\section{Hypothesis 1}

Dalarna's combination of predominantly private land ownership with (quasi)open access maintains a cherished public right, but at the expense of weakening and mis-aligning the incentives facing landowners, tourists, and commercial recreation businesses. This situation detracts from both the preservation of tourism's natural capital base and from developing tourism's economic potential. In Maine, private land ownership combined with the spread of restricted public access creates stronger economic development incentives, but it also builds momentum for irreversible real estate development, concentrated in areas with high scenic and recreational value.

Corollary 1: Sweden needs to rethink the rights and responsibilities associated with allemansrätten. Maine needs to rethink the high degree of landowner sovereignty and the determining role of market forces.

Corollary 2: Both jurisdictions need more effective planning and management of competing land uses at the landscape and ecosystem scale. A key challenge is to develop and use estimates of ecosystem carrying capacity as a way to reduce short-term peaking pressures as well as long-term resource depletion, especially irreversible land use conversion. Public ownership of unique and fragile lands is part of a sustainable nature tourism strategy, but it is not 'the' solution.

\section{Hypothesis 2}

Expanded commercial tourism may be a route to increased rural employment and economic growth, but it constricts recreational opportunities for local residents, representing an opportunity cost and an equity dilemma. Tourism growth may also generate socio-cultural conflicts between local residents and tourists (see Vail et al., 1998).

\section{Hypothesis 3}

With an open access regime such as Dalarna's, a shared 'land ethic' helps to counteract self-interested and shortsighted behaviour on the part of landowners and recreational users. However, under mounting peak demand pressures, voluntary action based on such an ethic will likely prove inadequate for environmentally sustainable nature tourism. 
Corollary 1: Land ethics are a form of cultural capital that may depreciate as tourism becomes more dependent on consumers lacking traditional users' knowledge and sense of responsibility for 'nature'.

Corollary 2: Land stewardship, and especially the priority given to preserving non-use values, erodes when corporate managers are pressured to maximise rents or liquidate land assets by shareholders. Weak land use regulatory institutions reinforce this tendency.

\section{Hypothesis 4}

Cooperative recreation management is an important tool for overcoming the scale mis-match between small landholdings and large effective management units. Landowner collaboration can achieve economies of scale, reduce transaction costs, and raise the return on investment in value-added tourism facilities.

Corollary: Collective bargaining between landowners and recreational users, such as sporting organisations and commercial tour operators, can produce 'win-win-win' situations, enhancing land owners' incentives and incomes, tourists' quality of experience, and resource conservation. Governmental agencies can play an important role in facilitating such arrangements.

\section{Research and Policy Implications}

Dalarna and Maine suffer from regional economic dualism. The economies of southeastern Dalarna and southern Maine have diversified and are thriving, but other regions - Dalarna's Bergslagen and northwestern mountains and Maine's northern interior and 'downeast' coast - face chronic economic distress, with high unemployment, out-migration of young people, and difficulty maintaining a base of public and commercial services. We agree with policy makers who believe tourism has both untapped capacity and demand-side potential to contribute to regional economic revitalisation and diversification - but with qualifications. As this paper's introduction (and the following Appendices) stress, sustainable tourism growth is not a sure thing. Some prime attractions face carrying capacity limits, and there is intense national and international competition to attract tourists.

Just as important, there are serious institutional impediments to sustainable tourism. In particular, we have hypothesised that core public policies, reinforced by long traditions and powerful interest groups, are 'part of the problem'. In the Dalarna case, three national policies are most clearly implicated. First, the high cost of inexperienced and low-skill labour blocks employment creation in small-scale tourism services. High labour costs drive up the price of those services, which means fewer tourists. High commercial service prices, especially meals and lodging, induce tourists to self-produce them. And high labour costs induce businesses to opt for labour-saving production methods. These are not new claims: the contradiction between Sweden's employment goals, on the one hand, and the high cost of inexperienced and low-skilled labour, on the other, has been a much studied and hotly debated issue throughout the 1990s. Second, Sweden's high value added tax on most tourism-related services reinforces the first two effects described above. In particular, it strengthens affluent Swedes' incentive to travel abroad and the less affluent to visit friends and relatives or 
vacation at home. It also leads some price-sensitive foreigners to vacation elsewhere. Third, and perhaps most controversially, we hypothesise that the venerable allemansrätten, as currently implemented, also impedes sustainable tourism development. Free public access to undeveloped land, combined with sharp demand peaks, contributes to short-term congestion and long term depletion of prime natural attractions. And free access to private land weakens owners' investment incentives.

Our hypotheses regarding Sweden's labour, tax and property institutions raise politically contentious issues; therefore they need to be further refined and tested before a public critique of existing policies or a proposal for policy reforms is offered. In any case, it is crucial to recognise that the hegemony of national policy in these areas severely limits the options of Dalarna policy makers.

The inconsistencies between these three institutional design features and what is needed for a truly sustainable tourism development are not limited to Sweden. Every central and north European nation now promotes tourism growth as an antidote to rural socio-economic distress and depopulation. For every one of them, however, some combination of high labour costs, high commodity taxes, and free recreational land access slows and distorts such growth. Low-skilled labour, for example, is comparably expensive in Germany, Switzerland, Norway, Austria and Denmark (EPI, 1999: Chapter 8). The value added tax stands at $20 \%$ or higher in Norway, Finland, Denmark and Austria (Brors, 2000). Further, Norway, Finland, Denmark, Germany, Austria and Switzerland each has its historically rooted version of the right of common access (Jäggi, 1998). The European Union members among these nations currently receive EU investment subsidies for tourism development in their distressed rural regions. The economic and social payoffs are vitiated, however, by the institutional obstacles described here. It is possible to imagine these nations reaching a clearer understanding of the contradictions embedded within these institutions and moving to harmonise them, either 'upward' toward a common European standard or 'downward' toward the more free market US pattern.

In the United States' federal system, Maine has greater constitutional authority than Dalarna to shape economic and land use institutions, although in basic labour regulations, federal statutes, such as the 1938 Fair Labor Standards Act, prevail. Maine's freedom of manoeuvre is also limited by powerful free market and private property rights traditions, not to mention competition with other states for tourist dollars (Vail et al., 1998). Although Maine's 'cheap labour' institutions undoubtedly boost sheer tourism employment, we hypothesise that the low quality of most jobs contradicts the state's livable wage goal, an equitable sharing of economic benefits, and the revitalisation of distressed rural regions. We also suspect that core property institutions are maladapted for sustainable tourism development. Ownership of Maine's vast North Woods is turning over rapidly and wildlands real estate development is accelerating, bringing irreversible changes to a vast multiple-use landscape. Maine's heretofore weak land use regulations and very limited public ownership of prime scenic and recreational lands jeopardise the future of nature tourism. Nonetheless, there are positive signs on several fronts, including cooperative recreational land management, purchases of land and conservation easements by conservation groups, a more systematic approach to land use zoning in the 'unorganised territories', and 
increasing public ownership. However, the public policy response has in essence been reactive and it may be 'too little, too late' to cope with the magnitude of change in Maine's North Woods.

Viewed from a larger national and international perspective, policy makers in several US states, as well as Maine, face a similar choice between fundamentally different tourism strategies. On the one hand, they can perpetuate the present institutional mix of competitive labour markets, low taxes, and quasi-laissez faire land use, which results in income patterns, community impacts, and environmental stress that bear a resemblance to East European or third world tourism (think of Maine as a 'chilly banana republic'). Alternatively, they may espouse the goals of livable tourism wages, host community vitality, and ecosystem health. Reaching these goals would require institutional innovations centring on greater human capital investments, progressive labour market policies, higher tax rates on tourism services, and more farsighted management of natural endowments.

Our hypotheses help to bring these larger stories of institutional adaptation and maladaptation into focus. Since the implications of our critique extend beyond regional tourism economies to core national policies, they are certain to be controversial. Thus, this paper's conclusions should be considered provisional: a launching point for continuing research.

\section{Correspondence}

Any correspondence should be directed to Professor David Vail, Department of Economics, Bowdoin College, 9700 College Station, Brunswick, ME 04011-8497,USA (d.vail@bowdoin.edu).

\section{Notes}

* This paper contains values in US dollars and Swedish kronor for various years between 1994 and 1999. Since exchange rates have fluctuated over the relevant period, the rule of thumb exchange rate used here is SEK 7.5/US\$1 (In 1999-2000, the rate has fluctuated between SEK 8.4 and SEK 9.3/US\$1). This should not impart any significant bias to the calculations or conclusions in the paper.

1. Estimates of tourism's economic scope and importance are ambiguous and often exaggerated. 'Satellite tourism accounts' have recently been derived from national income accounts, to reflect the fact that tourist services span many distinct industries and make up only part of total spending in most of them. Critics contend that satellite accounting remains crude. In any case, precise accounts for sub-national jurisdictions like Dalarna and Maine do not exist (Hansen \& Jensen, 1996; Nordström, 1996; Smith \& Wilton, 1997).

2. Vail et al. (1998) suggest that quality tourism jobs have a cluster of attributes including a 'livable wage', benefits (such as health insurance, paid vacation and pension contributions), job security, opportunities for skill acquisition and advancement, and workplace congeniality.

3. Maine's $5000 \mathrm{~km}$ of 'rock-bound coast' are also a tourist magnet, not discussed in this paper.

4. The overtime supplement applies to work between $8 \mathrm{pm}$ and $6 \mathrm{am}$, Monday to Friday, and 4 pm to 6 am on Saturday or Sunday. The current supplement for hotel and restaurant workers is SEK 13.50/hour (\$1.80), rising to SEK 23 (\$3.07) in 2000 (HoR, 1998).

5. Federal law requires that employees be paid 1.5 times normal wages for work beyond 40 hours/week; however, hotels, motels, restaurants and other eating establishments are exempt. 
6. Workers who earn tips, for example restaurant waiters and bar tenders, may be paid less than the minimum wage as long as combined wages and tips are at least $\$ 5.15 /$ hour. Employers who offer meals as a regular condition of employment may deduct the cost of meals from wages.

7. American workers are among the least unionised in any industrial society. Roughly $5.4 \%$ belong to unions in 'services' and $5.6 \%$ in 'wholesale and retail trade', two core tourism sectors. Unionisation is still lower among seasonal and part-time tourism workers (BLE, 1998; Murphy \& Hanson, 1995: ch. 4).

8. The survey summarised here included a cover letter indicating that the purpose was to demonstrate the high quality of jobs in lodgings and restaurants. This information probably imparted a strategic bias in two ways: first, respondents had an incentive to inflate reported wages and benefits; second, survey recipients with low wages and benefits had an incentive not to respond. The survey response rates were: lodgings $32 \%$; restaurants $36 \%$.

9. For recent years, nominal wages track real US and Swedish wages well: Sweden's consumer price index increased 25\% from 1990 to 1997 , compared to $24 \%$ in the USA (SCB, 1999: 495).

10. This figure is based on a 'guestimate' that half of gross tourism expenditures represent value added within Dalarna, while the rest 'leaks' into purchases of goods and services from elsewhere - e.g. food, fuel and vehicles. Sweden's satellite tourism accounts do not estimate value added at the county level.

11. See Hultkrantz (1995a:5-8), for a detailed analysis of how VAT changes affected tourism between 1990 and 1993.

12. In general, Sweden's pre-1990 business taxes discouraged development of small businesses, which predominate in Dalarna tourism. The old tax code favoured capital intensive and highly leveraged corporations relative to family owned, labour-intensive, and equity financed firms. Credit rationing in Sweden's financial markets also favoured large, established, capital-intensive firms (Henrekson \& Johansson, 1999). The 1990 tax reform slightly reduced these biases and probably encouraged tourism, but not enough to offset the higher VAT discussed in the text (Hultkrantz, 1995a).

13. Carbon emissions and energy conservation taxes add another SEK 3.6/litre.

14. New England state sales taxes are: Connecticut $6 \%$ plus surcharges of $3 \%$ on car rentals and $4 \%$ on entertainment; Massachusetts $5 \%$ plus $3 \%$ on lodgings; Rhode Island $7 \%$ plus $5 \%$ on lodging; and Vermont $5 \%$. New Hampshire, the outlier, has no general sales tax, but an $8 \%$ tax on lodgings (Rafool, 1997).

15. Until recently, this right was not mentioned in statutes; it is now included in the Environment Preservation Act and the Swedish Constitution. Unlike neighbouring Norway, however, Sweden still has no explicit legislation defining the content and limits of allemansrätten.

16. Pending federal legislation, based on the Land and Water Conservation Act, would yield Maine \$20-30 million/year for land acquisition.

17. Dalarna's surface area is 28,194 square $\mathrm{km}$ and the 1998 population was 282,198 . Northwestern Dalarna has a continental climate with cold, snowy winters and average temperatures of $12-14 \mathrm{C}$ in summer and -10 to $-12 \mathrm{C}$ in winter. Southeastern Dalarna has an average summer temperature of $16 \mathrm{C}$ and -6 to $-8 \mathrm{C}$ in winter. Annual precipitation averages $60-70 \mathrm{~cm}$, with up to $100 \mathrm{~cm}$ in the mountains $(\mathrm{SCB}, 1999)$.

18. Most skiers drive to Dalarna. There is no train service to the mountains and the scattered layout of ski lifts and lodgings makes a car handy.

19. Maine is the most northeasterly US state, bordering Canada's Quebec and New Brunswick provinces. Two-thirds of its 1.2 million residents are concentrated in the southern third of the state. The surface area is 86,500 square $\mathrm{km}$ and there are $5650 \mathrm{~km}$ of Atlantic Ocean coastline. The average summer temperature is $21 \mathrm{C}$ and winter is -5.5 C. Annual snowfall ranges from 152 to $228 \mathrm{~cm}$ (MOT, 1999).

20. Approximately $36 \%$ of all overnight visitors in a survey reported shopping at L.L. Bean, while 35\% shopped at factory outlet stores (Longwoods, 1997: 66).

21. These employment estimates should be taken with a grain of salt, since tourism employment cannot be estimated directly. Maine's State Planning Office's (SPO) uses 
an input-output model to estimate total tourism employment, including inter-industry linkages and multiplier effects (Rose, 1997). Comparing 49,900 full-time tourism jobs with average monthly employment of 615,000 in 1996 also gives rise to a problem of commensurability problem, since the total employment figure does not measure year round employment.

22. The lodging sector is viewed as a bellwether for the tourism sector, since it depends heavily on out-of-state visitors.

23. General touring spans activities ranging from museum visits to shopping and from lobster dinners to autumn leaf peeping.

\section{Appendix 1: Sketches of Tourism in Dalarna and Maine}

\section{Dalarna tourism}

Dalarna, located in Sweden's central interior, has a long tradition as a tourist destination, with internationally known attractions such as the homes of celebrated painters Carl Larsson and Anders Zorn, the Vasaloppet cross-country ski race and mid-summer celebrations around Lake Siljan. Dalarna's culture, nature, and major events present an image to foreign tourists of Sweden's 'essence'. Small lakes embedded in vast spruce and pine forests characterise much of the landscape, but there are also rolling agricultural landscapes in south and east. To the north and west, Dalarna is mountainous, with two major alpine ski resorts, Idre/Grövelsjön and Sälen (Sweden's largest) offering downhill and XC opportunities to the 12 million Swedes and Norwegians who live within a day's drive. Central Dalarna, around Lake Siljan, has strong traditions in music and dance, native costume, vernacular architecture, and crafts (including the famous carved Dala horse). The landscape is dotted with clusters of small red cottages on small plots that escaped Sweden's great partitioning. Major Siljan attractions include Leksand's Summerland, Mora's Santa Land park, Rättvik's mammoth Dalhalla open air concert hall, and Dalarna's most visited site, the Clas Ohlson department store, with over half a million yearly visitors.

Notwithstanding the county's reputation and attractions, recent tourism trends give reason for concern. Its national ranking as a tourist destination, measured by guest nights, has fallen from third to fourth in recent years. This is closely linked to the stagnation of skiing, the big grow th sector of the early 1990s. According to the Swedish Tourist Authority winter sports holidays are declining throughout Europe. The largest single group of tourists, Swedes visiting relatives and friends (accounting for 19\% of total guest nights), is also on the decline. Overall, Dalarna's tourism economy is nearly stagnant, although tourism is growing nationally and Dalarna policy makers are banking on tourism to boost the economy. Overall, Dalarna has a fairly mature tourist economy and a great deal has already been done to develop capacity and promote demand for the summer and winter activities with greatest market potential. The roster of special events ranges from world skiing championships to summer jazz and folk festivals. Increasing Swedish future tourist spending will depend on building a clientele for the spring and fall 'shoulder seasons', attracting more long weekend travellers, and expanding high value 'niche market' tourism. The big unknown is whether Dalarna, and for that matter Sweden, can attract significantly more foreign tourists. They currently account for only $5 \%$ to $10 \%$ of commercial guest nights (LD, 1998). 
There are two distinct seasonal tourist peaks: mid-June to August and Christmas to Easter. Although $80 \%$ of foreigner's visit in the summer, just $40 \%$ of total guest nights are recorded from May through September: $60 \%$ are recorded in the winter months, with alpine skiing the biggest draw. The Sälen area is Sweden's skiing leader with a 30\% market share. Sälen and Idre benefit from a competitive locational advantage over ski resorts farther north. ${ }^{18}$

During the January-February 'sport holiday' ski resorts operate close to full capacity, attracting parents with children of all ages. This national institution helps explain the large share of winter tourism in Dalarna, compared to Maine.

\section{Guest night statistics, expenditures, and employment}

Apart from the highly commercialised winter sport tourism in the mountains, which accounts for 30\% of total guest nights, most Dalarna tourists are either inhabitants of the region or other Swedes visiting relatives and friends or their own second homes. There are about 2.9 million overnight visitors per year and total guest nights of 14.5 million. (Both figures are almost exactly half of Maine's corresponding levels.) There are also 1.5 million day trips to Dalarna, less than one-tenth of Maine's level. Two-thirds of Dalarna's visitors but only one-third of Maine's make overnight stays. As mentioned, foreign tourists account for just $5 \%$ to $10 \%$ of total guest nights. The largest cohorts are Danes, with roughly a $40 \%$ share, and Germans at 35\%. Norwegians are Dalarna's closest neighbours, but with many similar attractions in their own country, they constitute only $10 \%$ (LD, 1998). Table A1 indicates the relative importance of major visitor groups, their spending, and the associated employment.

Total 1997 tourism spending in Dalarna has been estimated at SEK 4 billion (\$533 million), with direct employment in the tourist industry of 5000 full time equivalents (FTE) (LD, 1998). These figures are about one-sixth and one-eighth of Maine's corresponding levels. Not all benefits from tourism employment remain in Dalarna, since many seasonal employees, especially at ski resorts, pay income tax in other counties. There is no accurate estimate of the proportion of tourist spending that 'leaks' out of Dalarna in the form of purchases of food, fuel, etc. produced elsewhere. Using a 50-60\% 'guesstimate' for leakage (similar to Maine's), tourism spending probably accounts for about 3.1 to $3.9 \%$ of Dalarna's 1996 gross county product of SEK. 53.1 billion (NUTEK, 1999). This figure suggests that the economy's dependence on tourism is considerably less than Maine's and roughly on a par with Sweden as a whole.

Not surprisingly, Table A1 reveals that visitors staying overnight in commercial lodgings spend far more and generate more employment per visitor-day than visitors to relatives, friends and seasonal homes. Interestingly, business and conference tourism creates more spending and employment per guest night than any other tourism category.

Discussions of Swedish tourism commonly divide spending into four broad categories: lodging, transport, eating, and 'doing.' It is of note that 'Activities'the 'doing' part of tourism - account for just 14\% of Dalarna's tourist expenditures. At first glance this figure may seem low, considering that 'activities' ranging from skiing to folk festivals are what attract many tourists to Dalarna. In fact Dalarna's 'doing' share is high compared to other Swedish regions and to Maine, presumably due to the centrality of alpine skiing, an expensive activity. None- 
Table A1 Dalarna tourism statistics (percentages)

\begin{tabular}{||l|c|c|c||}
\hline Type of tourist & $\begin{array}{c}\text { Visitor days } \\
(\%)\end{array}$ & $\begin{array}{c}\text { Share of spending } \\
(\%)\end{array}$ & $\begin{array}{c}\text { Share of employment } \\
(\%)\end{array}$ \\
\hline Foreigners & 5 & 5 & 5 \\
\hline Swedes & 95 & 95 & 95 \\
\hline Of whom: & & & 15 \\
\hline $\begin{array}{l}\text { Visits to friends, relatives } \\
\text { or own leisure homes }\end{array}$ & 40 & 20 & \\
\hline Commercial lodging & & & 40 \\
\hline Winter & 30 & 40 & 15 \\
\hline Other & 10 & 10 & 20 \\
\hline Work-related & 5 & 15 & 5 \\
\hline Day visits & 10 & 10 & \\
\hline
\end{tabular}

Source: LD, 1998: 24

Table A2 Dalarna tourist spending and employment by activity

\begin{tabular}{|c|c|c|c|}
\hline Activity & $\%$ of Spending & $\%$ of Employment & Labour intensity ${ }^{a}$ \\
\hline Lodging & 26 & 48 & 1.8 \\
\hline Groceries & 18 & 8 & 0.4 \\
\hline Restaurants & 18 & 16 & 0.9 \\
\hline Transport $^{b}$ & 14 & 4 & 0.3 \\
\hline Shopping & 10 & 5 & 0.5 \\
\hline 'Activities' & 14 & 19 & 1.4 \\
\hline
\end{tabular}

a $\%$ of employment divided by $\%$ of expenditure

$\mathrm{b}$ including petrol

Source: LD, 1998: 25

theless, 'Doing' is probably tourism's most underdeveloped component, in terms of untapped potential for value-added and employment (Stiernstrand, 1998).

Table A2 reveals pronounced differences in the labour intensity of various tourist services, with lodging, tourism activities, and restaurant meals generating the most employment per krona spent. Grocery and other retail stores and transportation generate far less employment per krona. The data hint at the economic importance of encouraging growth in types of tourism that include commercial lodging and focus on commercial recreation activities, including value-added nature tourism. In reality, however, commercial guest nights increased by only 3.7\% in Dalarna between 1988 and 1997, less than one-half percent per year and well below the $6.4 \%$ national growth (TD, 1998b). By this measure, Dalarna's tourist industry has been nearly stagnant for a decade. The bright side of the picture economically is that stays at inexpensive camp grounds have declined sharply as visitors move 'up market' to more expensive and employment-creating accommodations.

\section{A statistical sketch of Maine tourism}

Maine hosted 27 million trips in 1996, as shown in Table A3. Day trips made up over two-thirds of the total, reflecting the tremendous expansion in short dura- 
Table A3 Trips to/within Maine by North Americans: $1996^{\mathrm{a}}$

\begin{tabular}{||l|c|c||}
\hline & \multicolumn{2}{|c|}{ Number of trips } \\
\hline & Day trips & Overnight trips \\
\hline Maine residents & $5.7 \mathrm{~m}(31 \%)$ & $1.6 \mathrm{~m}(18 \%)$ \\
\hline Other Americans & $6.8 \mathrm{~m}(38 \%)$ & $6.3 \mathrm{~m}(71 \%)$ \\
\hline Canadians & $5.7 \mathrm{~m}(31 \%)$ & $1.0 \mathrm{~m}(11 \%)$ \\
\hline Total & $18.1 \mathrm{~m}$ & $8.9 \mathrm{~m}$ \\
\hline
\end{tabular}

Source: Longwoods (1996: 12-15)

${ }^{\mathrm{a}}$ This study does not document foreign visitors other than Canadians

tion leisure travel in recent decades. Maine residents comprised about one-fourth of tourists and Canadians were by far the most important foreign group. The concentrated geographic origin of visitors is reflected in the fact that $30 \%$ of 'marketable' overnight visits were by Massachusetts residents and fully $71 \%$ were by residents of New England, New York, and Canada - the 30 million people who live within one day's drive of Maine. Of 20.1 million visits by Americans, $63.7 \%$ were 'marketable' pleasure trips, $28.9 \%$ were visits to friends and relatives, and 7.5\% were business-related (Longwoods, 1997: 38). In comparison to Dalarna, Maine has a much larger proportion of 'day trippers' and users of commercial lodgings.

The 5.7 million users of commercial lodgings averaged 5.3 nights per stay in 1996, giving Maine a total of 30.2 million commercial guest nights, or roughly twice Dalarna's level (Longwoods, 1997: 14). Survey research indicates that tourists spent $\$ 3.2$ billion in Maine in 1996: $\$ 2.2$ billion by visitors 'from away' and $\$ 1.0$ billion by residents. However, approximately $60 \%$ of this spending 'leaks' out of the state's economy in the form of federal taxes and direct and indirect 'imports' of food, fuel, materials, services, etc. A rough estimate of tourism's 1996 in-state value-added is $\$ 1.3$ billion, or $4.8 \%$ of gross state product (Longwoods, 1997: 23; MEGC, 1998: 5; Vail et al., 1998: 15). The spending breakdown in Table A4 reveals that three activities - shopping, eating, and sleeping - account for almost all tourist spending. ('food \& alcohol' refers to spending in eating and drinking establishments: tourist spending on groceries is included in the retail category.) The large retail component reflects the fact that millions of visitors shop at factory stores and outlet malls. Freeport's L.L. Bean retail store is Maine's most popular tourist site, with over 4 million annual visitors. ${ }^{20}$

It is estimated that tourism spending directly supported 49,900 full-time equivalent jobs in 1996, making it the state's largest employment generator, with

Table A4 Components of tourist spending (1991)

\begin{tabular}{||l|c|}
\hline Sector & \% of Tourist spending \\
\hline Retail trade & 44 \\
\hline Food \& alcohol & 24 \\
\hline Lodging & 17 \\
\hline Recreation \& tourist activities & 10 \\
\hline Transportation & 5 \\
\hline
\end{tabular}

Source: Vail et al., 1998: 43 
Table A5 Seasonal distribution of marketable overnight trips

\begin{tabular}{||l|c|}
\hline January-March & $9 \%$ \\
\hline April-June & $23 \%$ \\
\hline July-September & $50 \%$ \\
\hline October-December & $18 \%$ \\
\hline
\end{tabular}

Source: Longwoods, 1997: 53

$8.1 \%$ of all jobs. Input-output simulations suggests that when indirect employment is added, tourism accounted for 71,800 FTE jobs (this includes jobs in businesses supplying tourist service providers as well as multiplier effects $)^{21}$ (Longwoods, 1997: 27; Rose, 1997: 6; Vail et al., 1998: 14fn, 16fn). In sum, tourism comprises a very labour-intensive set of activities in Maine, generating $8.1 \%$ of Maine's employment from less than $5 \%$ of gross state product.

Tourism is seasonally skewed, as revealed in Table A5. In contrast to Dalarna, two-thirds of all visits are concentrated in the summer months of June-September. Despite the state's numerous alpine skiing facilities and outstanding snowmobile trail network, winter is a low tourist season, a sharp contrast with Dalarna, where winter is the peak season. Whereas Dalarna benefits from relative closeness to major population centres, Maine's ski areas face a locational disadvantage vis à vis New Hampshire and Vermont resorts closer to Boston and New York. Skiing quality in the eastern US is also inferior to the Rocky Mountain states. On the other hand, Fall 'leaf peeping' is a growing market segment, attracting affluent but busy working couples and retired people from the US Northeast (Carrier, 1998).

Roughly $70 \%$ of tourist spending is concentrated on the coast, where 9 of Maine's 10 most frequently visited host communities are located (Longwoods, 1997: 70; Vail et al., 1998:18). Nearly all non-Canadian visitors enter via interstate highway at Maine's southern boundary, passing through the south coastal region and often stopping to eat and shop there even when their ultimate destination is the North Woods or downeast coast. This resembles the position of Dalarna's Siljan region with tourists driving from greater Stockholm.

\section{Growing numbers, declining market share}

Policy makers claim that tourism is a prime growth sector, yet the available data show tourism value-added growing more slowly than overall state production during the macroeconomic recovery from 1991 to 1996: 0.5\%/year compared to $2.5 \%$ /year. From 1994 to 1996 , the growth tempo picked up, with marketable guest nights increasing by $2.8 \% / \mathrm{yr}$ and lodging employment rising $2.9 \% / \mathrm{yr}^{22}$ the tempo also appears to be accelerating during the current full employment boom. Preliminary 1997-98 data show lodging expenditure rising 7\%-8\%/year (MEGC, 1998: 22; Longwoods, 1997: 17; SPO, 1998: 12; Vail et al., 1998: 15).

Somewhat anaemic growth throughout 1996 dropped Maine's national rank as a tourist destination from 37 th to 38 th, measured by total spending. Even within the generally slow growing northeast tourism market, Maine's share of marketable trips fell from $4.5 \%$ to $3.8 \%$. As explained above, Dalarna has experienced a similar market share deterioration. There are several possible explanations for Maine's declining share. The 'hospitality industry' and the Maine Office of Tourism claim that the state spends too little on marketing and promotion compared to other states. Comparative advertising statistics bear this out, yet 
underlying demand trends also seem to work against Maine's major tourist attractions. Maine's national ranking in the category 'outdoor trips' has actually improved from 24th to 20th, but outdoor tourism is declining in popularity as a fraction of all trips and in absolute expenditure. Yet another of Maine's strengths, 'general touring', has been growing at only $1 \% / \mathrm{yr}^{23}$ Nationally, tourist spending grow th is fastest for services where Maine's competitive position is weak: casinos, theme parks, cruises, ski trips, and major events. Among these, only skiing has much current presence and clear future promise in Maine, although the state does increasingly promote cruises and special events (Longwoods, 1997: 6, 10, 30). These broad demand trends suggest that if Maine policy makers want tourism to be an engine of income and employment growth for the next century, they must encourage investment in services that match demand trends or find a more effective strategy to expand existing market niches, especially nature-based tourism.

\section{Appendix 2: Maps}
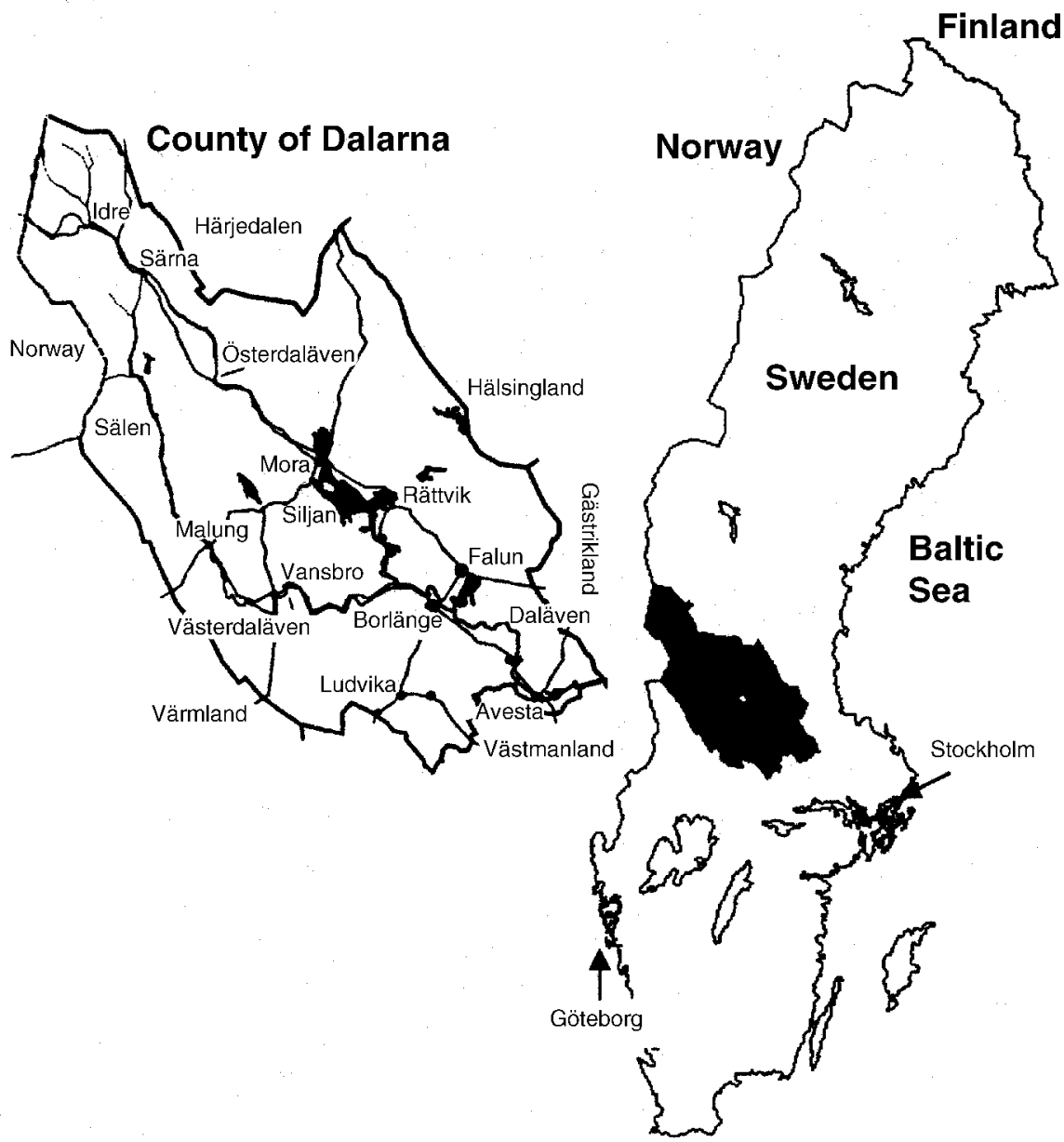

Figure 1 Dalarna County and its location in Sweden and Europe Source: Dalarna (2000) 


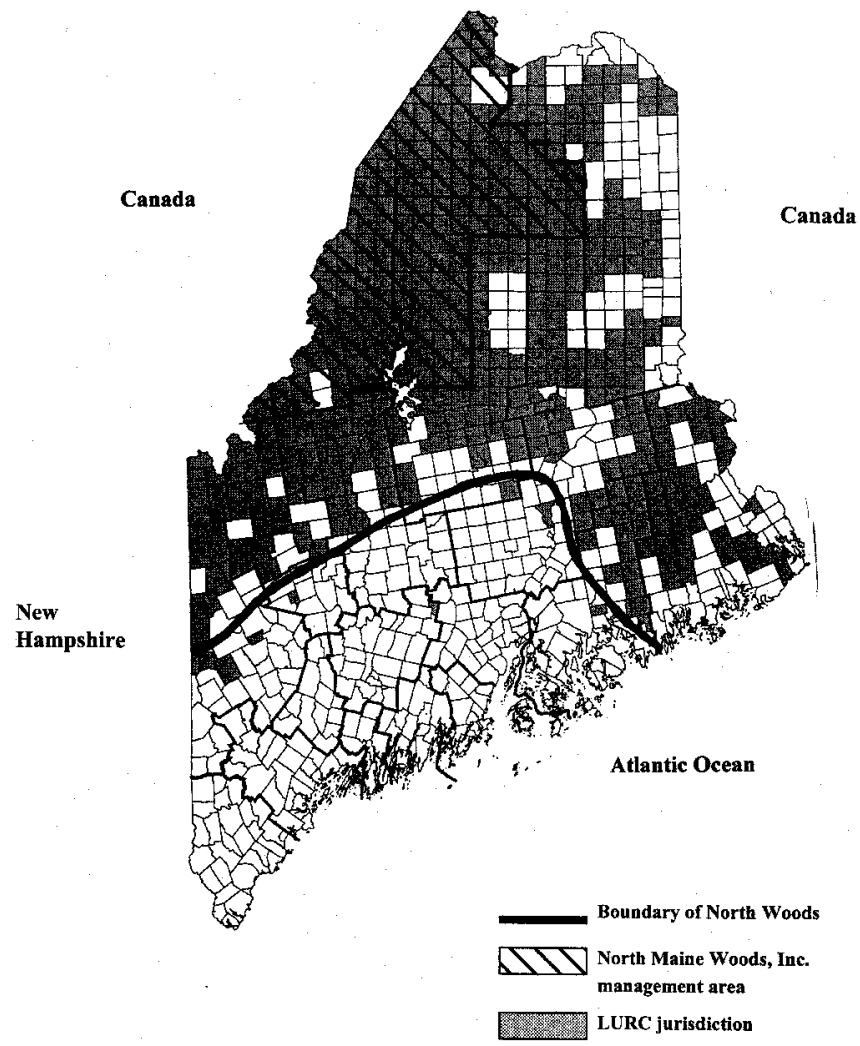

Figure 2 The Maine Woods

\section{References}

Androscoggin Land Trust (ALT) (1996) Maine Landowner Liability Explained. Lewiston, Maine.

Anttila, S. (1999) The snowmobile issue as a matter of common-pool resources. ETOUR Report. Mid-Sweden University.

Associated Press (AP) (1998) Rafting industry hits new record. Times Record (24 December). Brunswick, Maine.

Austin Associates (1997) Maine Lodging and Restaurant Wage Survey. For the Maine Office of Tourism (Department of Economic and Community Development). Augusta, Maine.

Austin, P. (1997a) Lake access controversy may just be getting started. Maine Times (5 June).

Austin, P. (1997b) Webber Timberland heir sells: Liquidation could follow. Maine Times (6 November).

Becker, C.D. and Ostrom E. (1995) Human ecology and resource sustainability: The importance of institutional diversity. Annual Review of Ecology and Systematics 26, 113-33.

Becker, G.S. (1965) A theory of the allocation of time. Economic Journal 75, 493-517.

Brors, H. (2000) Lägre skatter tvingas fram. Dagens Nyheter (10 August).

Bureau of Labour Education (BLE) (1991) Reducing the Health Care Cost Burden on Maine Consumers and Taxpayers. Orono, Maine: University of Maine.

Bureau of Parks and Lands (BPL) (1998) Maine Department of Conservation Fee Schedule. Augusta, Maine. 
Carrier, P. (1998) State tries to rake in leaf peepers. Maine Sunday Telegram.

Clarke, H. (1997) Australian tourism industry policy: A new view. Tourism Economics 3 (4), 361-77.

Colby, K.T. (1988) Public access to private land - allemansrätt in Sweden. Landscape and Urban Planning 15, 253-64.

Cowperthwaite, A. (1999) Managing director, North Maine Woods Inc. Telephone interview.

Dalarna (2000) Map of Dalarna, www.dalarna.se/karta, January.

Economic Policy Institute (EPI) (1999) The State of Working America. Ithaca, NY: Cornell University Press.

Eriksson, H. (1999) Director, HoA. Telephone interview.

Fisk, A. (1999) Maine Land Use Regulation Commission. Personal communication.

Folke, C., Pritchard, L., Berkes, F., Colding, J. and Svedin, U. (1997) The problem of fit between ecosystems and institutions. Beijer Institute Discussion Papers 108. Stockholm.

Hansen, C. and Jensen, S. (1996) The impact of tourism on employment in Denmark: Different definitions, different results. Tourism Economics 2 (4), 283-302.

Hasbrouk, S. (1998) The public access issue. Maine Fish and Wildlife (winter).

Henrekson, M. (1998) Högre sysslesättning genom en utvidgad marknadssektor. Ekonomisk Debatt 7, 515-26.

Henrekson, M. and Johansson D. (1999) Institutional effects on the evolution of the size distribution of firms. Small Business Economics12, 11-23.

Hotell och Restauranganställdas Arbetslöshetskassa (HoA) (1998) Bra att Veta om Arbetslösheten. Stockholm.

Hotell och Restauranganställdas Förbund (HoR) (1998) Kollektivavtalmellan Sveriges Hotell och Restaurangföretagareoch Hotell och Restauranganställdas Förbund, 1998-2001. Malmö, Sweden.

Hultkrantz, L. (1995a) On determinants of Swedish recreational domestic and outbound travel 1989-1993. Tax Reform Evaluation Report 7. Uppsala University.

Hultkrantz, L. (1995b) Hushållning med knappa resurser. ESO Rapport 15. Stockholm: Allmänna Förlaget.

Hultkrantz, L., Larsson S-O., Lundström M. and Paulsson B. (1987) Säsongsarbete och regionalpolitik. Cerum Report 2. Umeå, Sweden.

Idre Fjäll (1999) Marketing folder and field studies by author at Idre Fjäll, Sweden 10-13 June.

IFW (Maine Inland Fisheries and Wildlife Department) (1998a) Landowners and Land Users: How to Get Along: General Information. Augusta, Maine: Department of Conservation.

IFW (Maine Inland Fisheries and Wildlife Department) (1998b) Summary of Maine Hunting and Trapping Laws and Rules. Augusta, Maine: Department of Conservation.

Irland, L. (1993) Outdoor recreation supply in the Maine woods: Issues for the future. Renewable Resources Journal (Autumn), 6-15.

Irland, L. (1996) Land, Timber and Recreation in Maine's North Woods. Miscellaneous publication 730. Orono, Maine : Maine Agricultural Experiment Station.

Jäggi, S. (1998) Allemansretten ISveits, Tyskland og Østerrike. In B. Dahle (ed.) Friluftsliv I et Nytt Århundre. Oslo: Norges Idrettshøgskole.

Kimball, F. (1999) Maine Bureau of Insurance. Personal communication.

Landsorganisationen (LO) (Swedish Trade Union Confederation) (1999) The Swedish Labour Market - Facts and Figures. Stockholm.

Länsstyrelsen Dalarna (LD) (1998) Turismen i Dalarna in i det 21:a århundradet. Falun, Sweden.

Longwoods Associates (1997) Maine's 1996 Travel Year and 1997 Advertising Evaluation Summary Report. Montreal: Maine Office of Tourism.

LURC (Maine Land Use Regulation Commission) (1997) Comprehensive Land Use Plan (3rd rev). Augusta, Maine: Department of Conservation.

Maine Audubon Society (MAS) (1996) Valuing the Nature of Maine. Falmouth, Maine.

Maine Department of Labour (MDOL) (1995) Occupational Wage Rates, Maine Statewide. Augusta, Maine. 
Maine Department of Labour (MDOL) (1997) Occupational Wage Rates by Industry. Augusta, Maine.

Maine Department of Labour (MDOL) (2000) Occupational Wage Data: 1998. Augusta, Maine.

Maine Department of Transportation (MDOT) (1997) Strategic Transportation Plan. Augusta, Maine.

Maine Economic Growth Council (MEGC) (1998) Measures of Growth 1998. Augusta, Maine: Maine Development Foundation.

Maine Office of Tourism (MOT) (1995) Five Year Marketing and Development Strategy for Maine Tourism. Augusta, Maine: Maine Department of Economic and Community Development.

Maine Office of Tourism (MOT) (1999) State facts and information. www.visitmaine.com/facts, February.

Murphy, E. (1999) 'And the legislature's biggest chore is . . .'. Maine Sunday Telegram (17 January). Portland, Maine.

Murphy, W. and Hanson J. (1995) A Maine Guide to Employment Law. Orono, Maine: University of Maine, Bureau of Labour Education.

Nerhagen, L. (1997) Faktorer som påverkar färdmedelsvalet vid längre skidresor. CTS Working Paper 11. Dalarna University College, Sweden.

Nordström, J. (1996) Tourism satellite accounts for Sweden 1992-93. Tourism Economics 2 (3), $13-42$.

Nordström, J. (1999) Unobserved components in international tourist demand. Paper II in doctoral dissertation: Tourism and travel: Accounts, demand and forecasts, No 509. Umeå Economic Studies, Sweden.

NUTEK (1993) Skattereformen och turismen. R: 1993: 24. Stockholm.

NUTEK (1999) Regional Statistics Over Gross Regional Product for Dalarna. Dalarna: Länsstyrelsen.

Persson, A. (1999) HoR Dalarna section. Telephone interview.

Påhlson, A-M. (1997) Taxation and the market for domestic services. In I. Persson and C. Jonung (eds) Economics of the Family and Family Policies. London: Routledge.

Rafool, M. (1997) State tourism taxes. Travel and Tourism 2. Denver, CO: National Conference of State Legislatures.

Rose, G. (1997) Maine Regional Output Simulation Model. Augusta, Maine: State Planning Office.

Sahlberg, B. (1996) Resandets Grundläggande Struktur och Dynamik. Turistdelegationen. Stockholm.

Sahlberg, B. (1998) Kungar, Katastrofer, och Kryddor (om en världsspännande industri-turismen). Östersund, Sweden: ETOUR.

St John, C., Ditre, J. and Pohlmann, L. (2000) At Risk: Small Business Health Coverage. Augusta, Maine: Maine Center for Economic Policy.

Smith, S. and Wilton, D. (1997) TSAs and the WTTC/WEFA methodology: Different satellites or different planets? Tourism Economics 4 (1), 71-8.

SPO (Maine State Planning Office) (1998) Maine Retail Sales Quarterly Report. Third Quarter 1998. Augusta, Maine.

Statistiska Central Byrån (SCB) (1999) Statistisk Årsbok 1998 (Official Statistics of Sweden). Stockholm.

Stiernstrand, O. (1998) Riktade studier för utveckling av svensk turism - studie gjord på uppdrag av Turistdelegationen U 1998: 1. Östersund, Sweden: ETOUR.

Svensk författningssamling (SFS) (1982) Arbetstidslagen 673. Stockholm.

Svenska Turistföreningen (STF) (1996) Svenska Turistföreningens Årsbok 1997. Dalarna. STF publication no 3183.

Turistdelegationen (TD) (1996) Sunt Förnuft - Grunden För en God Byråkrati. Stockholm.

TD (1998a) Turismen Behöver Välutbildade Medarbetare. Stockholm.

TD (1998b) Hållbar Utveckling i Svensk Turistnäring. Stockholm.

Vail, D. and Hillard, M. (1997) Taking the High Road: Human Resources and Sustainable Rural Development. Augusta, Maine: Maine Center for Economic Policy (Ford Foundation funding). 
Vail, D. and Hultkrantz, L. (2000) Property rights and sustainable nature tourism: Institutional adaptation and mal-adaptation in Dalarna and Maine. Ecological Economics.

Vail, D. and Kavanaugh, W. (2000) Livable Wages in Maine Tourism? Augusta, Maine: Maine Center for Economic Policy.

Vail, D., Lapping, W.R. and Cote, M. (1998) Tourism and Maine's Future. Augusta, Maine: Maine Center for Economic Policy (Maine Community Foundation funding).

Westergård T. (1999) Managing director of Lövåsgården. Personal communication.

Westholm E. (1992) Mark, människor och moderna skiftesreformer i Dalarna. Geografiska regionstudier 25 (Phd thesis). Uppsala. 